Finance and Economics Discussion Series Divisions of Research \& Statistics and Monetary Affairs Federal Reserve Board, Washington, D.C.

\title{
Job Creation and Housing Construction: Constraints on Metropolitan Area Employment Growth
}

\author{
Raven E. Saks \\ 2005-49
}

NOTE: Staff working papers in the Finance and Economics Discussion Series (FEDS) are preliminary materials circulated to stimulate discussion and critical comment. The analysis and conclusions set forth are those of the authors and do not indicate concurrence by other members of the research staff or the Board of Governors. References in publications to the Finance and Economics Discussion Series (other than acknowledgement) should be cleared with the author(s) to protect the tentative character of these papers. 


\title{
Job Creation and Housing Construction: Constraints on Metropolitan Area Employment Growth
}

\author{
Raven E. Saks \\ Federal Reserve Board of Governors
}

September 22, 2005

\begin{abstract}
Differences in the supply of housing generate substantial variation in housing prices across the United States. Because housing prices influence migration, the elasticity of housing supply also has an important impact on local labor markets. Specifically, an increase in labor demand will translate into less employment growth and higher wages in places where it is relatively difficult to build new houses. To identify metropolitan areas where the supply of housing is constrained, I assemble evidence on housing supply regulations from a variety of sources. In places with relatively few barriers to construction, an increase in housing demand leads to a large number of new housing units and only a moderate increase in housing prices. In contrast, for an equal demand shock, places with more regulation experience a 17 percent smaller expansion of the housing stock and almost double the increase in housing prices. Furthermore, I find that housing supply regulations have a significant effect on local labor market dynamics. Whereas a 1 percent increase in labor demand generally leads to a 1 percent increase in the long-run level of employment, the employment response is less than 0.8 percent in places where the housing supply is highly constrained.
\end{abstract}

Email: raven.e.saks@frb.gov. I would like to thank Leah Platt Boustan, Chris Foote, Carola Frydman, Ed Glaeser, Caroline Hoxby, Larry Katz, and Abigail Waggoner for many helpful comments and suggestions. I am also grateful for the financial support provided by the Multidisciplinary Program in Inequality \& Social Policy, the Taubman Center for State and Local Government, the Lincoln Institute for Land Policy and the Joint Center for Housing Studies at Harvard University. The views presented are solely those of the author and do not necessarily represent those of the Federal Reserve Board or its staff 


\section{Introduction}

A growing literature argues that labor migration is one of the primary mechanisms through which metropolitan areas adjust to changes in local economic conditions (Blanchard and Katz 1992, Gallin 2004, Topel 1986). Models of an individual's migration decision suggest that a prospective migrant chooses a location by comparing the relative wage in each area to the cost of moving. Because housing is a large share of the household budget, the level of housing prices has a substantial impact on the real value of wages across geographic areas. ${ }^{1}$ As a result, areas with high housing prices will attract fewer migrants (Gabriel et al. 1993, Johnes and Hyclak 1999).

Because housing markets influence migration, local employment growth depends critically on the capacity of the construction industry to accommodate increases in housing demand. In places where residential construction responds to new demand without difficulty, workers will move into the area with little change in housing prices. In contrast, if new construction is constrained, an increase in demand will lead mostly to higher housing prices. As high housing prices discourage further migration, firms experiencing an increase in product demand will be deprived of an important source of additional labor. Thus, the elasticity of housing supply is a key factor in determining how labor markets adjust to changes in local economic conditions. $^{2}$

To illustrate the connection between housing and labor markets, Figure 1 graphs the change in the logarithm of employment from 1980 to 2000 against the log change in the housing stock in individual metropolitan areas of the United States. ${ }^{3}$ The figure shows a strong positive correlation between the two variables, as the areas with the highest employment growth have also experienced the largest amount of residential construction. Clearly, in the long run metropolitan area employment is strongly tied to the availability of housing.

\footnotetext{
${ }^{1}$ In 2002, households in the United States spent $19.2 \%$ of average annual expenditures on shelter (Consumer Expenditure Survey 2002, U.S. Bureau of Labor Statistics, Table 4).

${ }^{2}$ Although a number of studies have examined the correlation between housing prices and migration, only a few specifically address the effect of the housing supply on local labor markets. One example is Case (1991), who discusses this issue in the context of rising labor demand in Boston in the 1980s. Also, Bover et al. (1989) analyze the effect of regional housing market constraints on migration flows in the U.K. Neither of these papers attempts to identify the effect of housing supply constraints separately from housing demand, as I will do in this paper.

${ }^{3}$ In this figure and in all of the analysis that follows, metropolitan areas are defined using the 1999 Census definitions of PMSAs and NECMAs. County-level data are aggregated to the metropolitan level so that changes in metropolitan area boundary definitions will not affect the number of people or housing units in a location. See the Appendix for details.
} 
Over shorter time horizons, there are various ways that an area could adjust to a positive labor demand shock without building additional housing units. For example, a lower unemployment rate or increased labor force participation among existing residents can generate higher employment without an influx of new migrants. Moreover, a growing population could be accommodated by an increase in the share of occupied housing units or in the number of people per household. Despite these, and other, margins of adjustment, the correlation between changes in employment and the housing stock at higher frequencies is strong. Controlling for year and metropolitan area fixed effects, a simple OLS regression of annual log changes in employment on annual log changes in the housing stock yields a coefficient of 0.57 (with a standard error of 0.03). ${ }^{4} \quad$ Therefore, growing cities must confront the issue of where new workers will live.

In this paper, I explore the effect of the housing supply on metropolitan area labor markets. To identify the degree of housing supply regulation in individual metropolitan areas, I assemble evidence from several surveys of local land use policy and other sources. There is considerable heterogeneity in the extent of regulation across locations, and these different regulatory environments have led to significant variation in the elasticity of housing supply. These constraints have had a considerable impact on housing markets during the past twenty years, as areas with a constrained housing supply have experienced less construction and higher housing price inflation than less regulated locations. After exploring the effect of these regulations on the housing market, I develop a simple model to show how the elasticity of housing supply impacts local labor markets. Specifically, a labor demand shock should result in lower employment growth, higher wages and higher housing prices in places with an inelastic housing supply. Consistent with this theory, the long-run response of employment to an increase in labor demand is about 20 percent lower in metropolitan areas with substantial housing supply regulation.

Constraints on the housing supply further imply that labor will not be allocated efficiently across geographic areas. In the standard case where migration flows freely, a local productivity

\footnotetext{
${ }^{4}$ Other research also shows that these margins of adjustment appear to be small. Blanchard and Katz (1992) find that labor force participation and unemployment account for about 50 percent of the impact of a labor demand shock in the first year, and that these factors become less important over longer time horizons. Hwang and Quigley (2004) find that vacancy rates are only weakly related to labor market conditions in metropolitan areas. Glaeser, Gyourko and Saks (2004) also show that changes in vacancy rates and household size only explain a small fraction of the variance of changes in population across cities.
} 
shock will lead to an increase in aggregate output as workers move from less productive to more productive locations. However, by restraining migration, housing supply regulations reduce this aggregate benefit. If housing supply regulations reduce migration by 20 percent, the aggregate gain from a local productivity shock will be 18 percent smaller than if the housing supply, and therefore employment growth, were less constrained.

\section{Section 2: Housing Supply Regulations Across Metropolitan Areas}

\subsection{Relationship between Land Use Regulation and the Elasticity of Housing Supply}

Because this paper emphasizes the supply of housing, I start with a basic model relating variation in the elasticity of housing supply to local regulatory constraints. A simple housing supply equation expresses housing prices as a function of the size of the housing stock:

$$
p_{i t}=\theta_{i} h_{i t}+\eta_{i t}
$$

where the subscript $i$ indexes metropolitan areas and $t$ indexes time. When the variables are expressed in logarithms, the parameter $\theta_{i}$ represents the inverse of the elasticity of housing supply.

Even if the residential construction industry were perfectly competitive, there are several reasons to expect an upward-sloping supply curve. Environmental constraints raise the marginal cost of construction by driving up the cost of land and creating a need to use more expensive building materials. Also, government regulations increase the cost of construction in a variety of ways. A few examples include delays in building permit approvals, impact fees, height and lot size requirements, and growth controls. These factors raise the marginal cost of construction for a larger number of housing units, which is reflected by the positive slope of the supply curve, $\theta_{i}$. Because constraints on new construction are more binding in some areas as opposed to others, I index this parameter by $i$ to emphasize that this elasticity can vary across locations.

A natural way to measure $\theta_{i}$ in each metropolitan area would be to estimate a separate regression for each place using data on housing prices and quantities. Assuming for a moment that the housing stock is exogenous, the coefficient on $h_{i t}$ would provide a direct estimate of the elasticity of housing supply in each location. ${ }^{5}$ However, estimating separate coefficients would

\footnotetext{
${ }^{5}$ In Saks (2004), I use an instrumental variable strategy to estimate the responses of annual changes in the housing stock and housing prices to a labor demand shock in 131 individual metropolitan areas. I find substantial heterogeneity in the elasticity of housing supply across metropolitan areas that is correlated with housing supply regulations. Other related research includes Green et al. (1999), who estimate metropolitan-specific elasticities from
} 
require a long time series of data for each individual location in order to obtain precise estimates. Instead, I follow an alternative strategy by using information on land use regulations and other metropolitan area characteristics to evaluate how the responsiveness of housing supply varies across space.

To observe the effect of regulation on the housing supply, we can express the elasticity of housing supply as a function of regulation $\left(r_{i}\right)$ and other factors $\left(u_{i}\right)$ :

$$
\theta_{i}=\theta_{0}+\pi r_{i}+u_{i}
$$

Through the parameter $\pi$, differences in housing supply regulation generate variation in the elasticity of housing supply across locations. Substituting equation (2) into (1) shows that $\pi$ can be estimated from the interaction of the housing stock with these regulations:

$$
p_{i t}=\theta_{0} h_{i t}+\pi r_{i} h_{i t}+u_{i} h_{i t}+\eta_{i t}
$$

Therefore, even without estimating $\theta_{i}$ directly, land-use regulations can be used to assess the degree to which the elasticity of housing supply varies across locations. In the analysis that follows, I create an index of housing supply regulation from a variety of surveys on local land use policy. As suggested by equation (3), the interaction between this index and changes in the housing stock will reveal the effect of the housing supply on housing market dynamics.

\subsection{Measuring Housing Supply Regulations across Metropolitan Areas}

Government regulations can create impediments to residential construction in numerous ways. One reason that laws regulating residential construction vary so widely is that land use policy is generally under the control of local governments (Fischel 1985). The political environment in each individual municipality shapes the degree of regulation and the form that it takes, leading to large degree of heterogeneity across locations.

Because political efforts to control residential development are so diverse, it is difficult to summarize the extent of regulation in a manner that is comparable across a large number of locations. Consequently, empirical surveys of land use policies require a substantial amount of resources and are generally limited to a select number of metropolitan areas. To characterize the

a reduced-form regression of prices on quantities, Evenson (2003), who estimates area-specific elasticities from changes in employment. However, these studies do not identify the slope of the supply curve from exogenous changes in housing demand. While housing demand is an inelastic function of the number of households in the short run, over time demand can change in response to relative prices across locations. If the elasticity of housing demand varies across locations, then the reduced-form parameters will reflect differences in the elasticity of both supply and demand. 
strength of housing supply regulation across metropolitan areas, I combine evidence from several land use surveys and other sources of information. This section contains a brief discussion of four different types of regulation that are included in the index. A complete description of each of the surveys and how the index is constructed can be found in the Appendix.

The first type of regulation I consider is related to the approval of local building permits. Many barriers to residential construction are embodied in the process of obtaining a permit for new construction, and the vast majority of municipalities require some form of building permit for both the construction of new housing units and the renovation of existing structures. ${ }^{6}$ Zoning ordinances, height and lot-size restrictions, as well as outright quantity restrictions can all result in the denial of a building permit. Moreover, a lengthy and complicated bureaucracy associated with the application process can delay or prevent construction all together. I measure these constraints using information from a survey conducted by the Wharton Urban Decentralization Project (Wharton). The survey reports several questions related to building permits including the average number of months for permits to be approved and the fraction of permit applications approved. ${ }^{7}$ I combine these survey responses into a single index that reflects the complexity of the permit-issuing process. This index, as well as all of the other indexes described below, is scaled to be increasing in the amount of regulation with a mean of 0 and a standard deviation of 1.

A second common barrier to new construction is growth controls, which are explicit limits on the number of new housing units that can be built within a year. These regulations have become increasingly popular as a tool for managing development during the past two decades (Dubin et al. 1992, Seidel 1978). To measure the extent to which growth controls are used in different metropolitan areas, I combine information from the Wharton survey and the Fiscal Austerity and Urban Innovation project (FAUI), both of which asked city managers to rate the importance of restricting construction in order to limit population growth.

\footnotetext{
${ }^{6}$ According the Census Bureau, more than 95 percent of all residential construction is located within an area subject to local building permit requirements (see their definition of permit-issuing places at http://www.census.gov/const/www/permitsindex.html).

${ }^{7}$ It is possible that the permit-approval process would take longer in places experiencing a large unanticipated increase in housing demand. Furthermore, if strict regulations discourage potential builders from applying for building permits, the fraction of permits approved would not necessarily be lower in locations with a high degree of regulation. This would tend to dampen the variation of permit approvals across locations, making it more difficult to observe any effect of these regulations on housing markets. Despite these drawbacks, these data have been the primary source of cross-metropolitan area information on housing supply regulation (Malpezzi 1996, Mayer and Somerville 2000).
} 
A third constraint on residential construction stems from the desire to protect certain areas from development for historic reasons. For example, many cities have a historic district to preserve buildings of historic significance or the historic character of the neighborhood. Even in suburban or rural areas, development can be limited by the existence of historic landmarks, archeological sites, and old battlegrounds. To create a measure of the extent that residential construction might be limited by concerns of historic preservation, I use a comprehensive database provided by the National Register of Historic Places (NRHP). The index combines information on the amount of land area reserved for historic districts and sites and the number of other historic buildings and structures per square mile.

Although the majority of land use regulations are imposed by local jurisdictions, state governments also play a role in influencing patterns of development. For example, a state may restrict development in certain areas, mandate certain types of land use planning or environmental impact analyses, or control the development of new towns. Therefore, the fourth type of supply constraint I consider is based on a study of state regulations conducted by the American Institute of Planners (AIP).

The relationship between conditions in the housing market and each of these measures of housing supply regulation can be seen in Figures 2 and 3. As illustrated by the positive regression lines in Figure 2, all 4 types of regulation are positively correlated with growth in housing prices from 1980 to $2000 .^{8}$ Conversely, Figure 3 shows that increases in the residential housing stock have been smaller in places with more permit restrictions or historic preservation. These effects are exactly what one would expect if these regulatory constraints cause the housing supply to be more inelastic.

A bit surprisingly, there is no clear negative relationship between the index of growth controls and new residential construction. One potential explanation for this result is that the areas where growth controls are implemented are not random. In particular, it may be only in

\footnotetext{
${ }^{8}$ Housing prices are calculated using the OFHEO repeat-sales price index and deflated using the PCE chain-price index. Because housing is durable, a decline in demand should mainly lead to a large fall in prices and not a decrease in the housing stock. A sustained low level of demand over a period of years can lead to a high vacancy rate, so that even small increases in demand in places like Detroit can have no effect on construction. See Glaeser and Gyourko (2001) for a discussion of the dynamics of housing markets in declining locations. Since I am mainly interested in the effect of an increase in demand, metropolitan areas where demand is low have been omitted from these figures and from all of the remaining analysis in this section (see the Appendix for the method used to identify low-demand areas, and a list of those areas).
} 
places where there is a substantial amount of housing demand that current residents will have an incentive to fight further development. If places with more regulation are also areas with greater housing demand, then the estimated effect of regulation on the quantity of housing will be biased towards zero, while the effect on housing prices will be biased upward. One factor that should mitigate this concern is that the majority of the regulations used in this analysis were measured during the late 1970s or early 1980s, a time period before the conditions in the housing market are examined. However, to the extent that omitted demand factors might be persistent over time, the simple correlations shown in the figures will still be biased. In the empirical analysis below I will address this problem by examining the dynamics of housing markets within metropolitan areas instead of comparing average differences in prices and quantities across locations.

To create a single measure of housing supply regulation for each metropolitan area, I combine the regulations discussed above with information from two other surveys that concern the general degree of housing supply regulation in each location. The first is a survey of the Regional Council of Governments, which estimated the fraction of suburban land area made unavailable for development as a result of government regulation. The second is a survey conducted by the International City Management Association, which asked members how frequently zoning or environmental regulations were altered to facilitate economic development. Table 1 lists each of the sources that are used, the time period and type of geographic areas that are covered.

Among these six sources of information, only the AIP survey of state regulations and the index of historic preservation can be calculated for every metropolitan area in the United States. The four other surveys were conducted in a limited number of metropolitan areas, and the geographic areas covered by each one are considerably different. Out of the 318 metropolitan areas in the United States, only 17 contain information on all 6 of the surveys. Rather than limiting the analysis to these places, I use a set of OLS regressions to predict missing values of each survey from observed values of the other surveys. The final index includes all of the locations with non-imputed information for at least two of the four local surveys, for a total of 83 metropolitan areas.

A list of the most and least regulated metropolitan areas according to this measure can be found in Table 2, and the complete ranking is shown in Appendix Table 2. It comes as no surprise to find that San Francisco, CA, Seattle, WA and New York, NY are among the most 
highly regulated locations. Areas with the least amount of regulation include Nashville, TN, Pueblo, CO and Champaign, IL. The two panels of Figure 4 show that places with a large amount of regulation have experienced higher housing price inflation and lower residential construction during the past twenty years.

\subsection{Effects of Regulation on the Housing Market}

Although the correlations in Figure 4 are suggestive, metropolitan areas differ along many unobservable dimensions that can make it difficult to sort out the effect of housing supply from other factors. Instead of using this cross-sectional comparison, the impact of the housing supply can also be found by examining relative housing market dynamics within metropolitan areas over time. Therefore, I estimate a fixed-effects version of equation (3):

$$
p_{i t}=\theta_{0} h_{i t}+\pi r_{i} h_{i t}+x_{i}+d_{t}+\varepsilon_{i t}
$$

By including year and metropolitan area fixed effects in the regression, the effect of regulation is identified from deviations of construction and housing price growth from locationspecific and time-specific averages. Thus, the estimates will not be biased by omitted factors like geographic amenities that are constant over time.

Even with fixed effects in the regression, changes in the housing stock are likely to be correlated with the error term $\varepsilon_{i t}$. Therefore, I replace $h_{i t}$ with a variable reflecting shocks to housing demand. To measure these shocks, I use annual changes in labor demand as predicted from the industrial composition of each metropolitan area (Bartik 1991). The idea behind this strategy is that firms in the same industry face similar conditions in the product market, and thus are likely to have similar demands for workers, irrespective of geographic location. Assuming that every firm would like to hire workers at a rate equal to the change in employment in its industry, employment growth for each metropolitan area can be predicted as a weighted average of national industry growth rates, where the weights are determined by the industrial composition of the area. ${ }^{9} \quad$ For example, predicted labor demand in areas with a large share of automobile manufacturing plants will be high when the automobile industry is hiring more workers

\footnotetext{
${ }^{9}$ To ensure that these employment growth predictions are not related to local conditions, the calculation for each metropolitan area subtracts industry employment in that individual area from the national industry total. In other words, the shocks are based on industrial employment growth outside of the specific metropolitan area in question. I also subtract national employment growth from these adjusted industry growth rates so that an increase in aggregate demand will not lead to a change in predicted labor demand. Thus, these shocks reflect purely relative changes in the local demand for labor. See the Appendix for the exact formula used for calculating these shocks.
} 
nationally relative to firms in other industries. Because employment in the construction industry is likely to be related to the amount of housing supply regulation in an area, I exclude the construction industry when calculating these labor demand shocks.

Through the migration of workers, an increase in labor demand should lead to an increase in the demand for housing, and therefore an increase in residential construction. However, if housing supply regulations limit new construction, this effect will be smaller in areas with a more inelastic housing supply. Similarly, the effect of an increase in labor demand on housing prices will be larger in places with more housing supply regulation. Therefore, I estimate a regression of annual changes in the logarithm of housing prices and the housing stock on the labor demand shocks and an interaction with the index of housing supply regulation. ${ }^{10}$

The first and fourth columns of Table 3 show the effect of a labor demand shock on annual changes in the housing stock and housing prices. On average, a 1 percent increase in labor demand is associated with a 0.25 percent increase in the housing stock and a 0.8 percent increase in housing prices. Consistent with the notion that regulations decrease the elasticity of housing supply, the interaction of the labor demand shocks with the index of housing supply regulation is negative for housing quantities and positive for housing price inflation. However, because housing is durable, the effect of an increase in housing demand is likely to be substantially different from the effect of a decrease in demand (Glaeser and Gyourko 2001). To account for these differences, the regressions in the second column and fifth columns include a dummy variable indicating years when the labor demand shock predicts an absolute decline in local demand. This indicator is also interacted with both the labor demand shock and the demand•regulation interaction, so that housing market dynamics are allowed to differ completely in response to positive and negative shocks. In areas experiencing an increase in labor demand, the magnitude of the interaction between the labor demand shock and housing supply regulation becomes larger and more precisely estimated. ${ }^{11}$ Whereas a 1 percent increase in demand would lead to a 0.35 percent increase in the housing stock in an area with an average amount of housing supply regulation, the effect of same demand shock would be 17 percent smaller in an area with a 1 standard deviation higher value of the housing supply regulation index. Thus, the regulations

\footnotetext{
10 Annual changes in the housing stock are calculated from information on the number of residential building permits issued in each county. See the Appendix for details.

${ }^{11}$ The coefficients on the negative shock terms show that fall in labor demand has a large effect on housing prices and a smaller impact on the quantity of housing. This result is what would be expected if the housing supply is very inelastic in the downward direction.
} 
represented by this index appear to have a significant damping effect on residential construction. The magnitude of the effect on housing prices is also larger than previously estimated, although it is not significantly different from zero.

The third and sixth columns of the table further explore the dynamics of housing markets by controlling for the lagged dependent variable and an interaction of this lagged variable with housing supply regulation. ${ }^{12}$ Consistent with other evidence on the dynamics of metropolitan area housing prices, housing price inflation displays a large degree of serial correlation (Capozza et al. 2002, Case and Shiller 1989) and so controlling for lagged housing price inflation allows for a more precise estimation of the coefficients in the housing price regression. In this specification, the effect of a demand shock on housing price inflation is twice as large in a metropolitan area with a 1 standard deviation greater degree of housing supply regulation. Taken all together, the results in this table demonstrate that this index of regulation reflects meaningful differences in the elasticity of housing supply across locations. ${ }^{13}$

\section{Section 3: A Model of Housing and Labor Markets}

Through their effect on construction and housing prices, constraints on the supply of housing will also impact local labor markets. In this section, I develop a simple framework to illustrate the connection between housing and labor markets. I begin with the basic model of regional labor markets from Blanchard and Katz (1992) and extend it to explicitly incorporate local housing markets. The model illustrates how the elasticity of housing supply influences the migration patterns of workers and consequently alters the effect of an increase in labor demand.

The economy is made up of a large number of metropolitan areas, each indexed by $i$. In each place, the marginal product of labor declines with the level of employment, so that the demand for labor is downward sloping:

$$
w_{i t}=-\delta n_{i t}+z_{i t}
$$

\footnotetext{
12 The coefficient on a lagged dependent variable is biased in panel data models with fixed effects and serially correlated errors (Nerlove 1971). However, this bias decreases as the time-series dimension of the panel increases, and analytic expressions derived by Nickell (1981) suggest that the bias in panels such as this one with 20 observations for each areas is small.

${ }^{13}$ A remaining concern is that housing supply regulation may correlated with omitted factors like the age of the city or geographic constraints that might cause the labor demand shock to have a smaller effect in highly-regulated locations. However, the results in this table are robust to including interactions of the labor demand shock with the following measures of differences in productivity and the supply of land across locations: metropolitan area age, the logarithm of January temperature, density of housing units in 1980, and the fraction of total area taken up by water.
} 
where $w_{i t}$ is the wage and $n_{i t}$ is employment in area $i$ at time $t$. All variables are measured in logs and reflect deviations from the national average. The variable $z_{i t}$ represents shifts in the labor demand curve, and is assumed to contain both a unit root and drift component:

$$
z_{i t}-z_{i t-1}=x_{i}^{d}+\varepsilon_{i t}^{d}
$$

The fixed city-specific factors in this equation capture any local characteristics that cause labor demand to differ systematically across locations. For example, each metropolitan areas produces a different combination of goods, and so we would expect the labor demand curves in each location to shift differentially as the relative demand for goods changes over time. These factors imply that cities are likely to grow systematically at different rates, a prediction that fits the patterns of local employment growth well during the post-WWII period (Blanchard and Katz 1992). A shock to the relative productivity of an area is reflected in the idiosyncratic error $\varepsilon_{i t}^{d}$. Because the position of the demand curve follows a random walk, the effects of all labor demand shocks are permanent.

The supply of labor in each area is determined by the size of the population. There is no adjustment through changes in hours or unemployment, meaning that the supply of labor in the short run is completely inelastic. Over time, workers respond to relative differences in wages and housing prices by moving between locations. Migration into an area increases with the relative level of wages $\left(w_{i t}\right)$ and decreases with the relative level of housing prices $\left(p_{i t}\right)$. Migration also depends on fixed location-specific factors $\left(x_{i}^{s}\right)$, such as weather, that cause some areas to be permanently more attractive than others.

$$
n_{i t}-n_{i t-1}=\beta w_{i t-1}-\gamma p_{i t-1}+x_{i}^{s}+\varepsilon_{i t}^{s}
$$

Through the migration decision, the state of the housing market will impact equilibrium wages and employment. To model the housing market, I assume that everyone in the population works and that all workers must live in a separate house, so that housing demand, and therefore the equilibrium size of the housing stock, is equal to employment. On the supply side of the housing market, I use an expression similar to equation (1) where the size of the housing stock is equal to the size of the population:

$$
p_{i t}=\theta_{i} n_{i t}+x_{i}^{p}+\varepsilon_{i t}^{p}
$$

As discussed in Section 2, the parameter $\theta_{i}$ reflects the inverse of the elasticity of housing supply. A high value of $\theta_{i}$ means that the housing supply is more inelastic, as a given increase 
the size of the housing stock is translated into higher prices. The supply of housing is also allowed to depend on any fixed city-specific factors $\left(x_{i}^{p}\right)$ factors that might create persistent differentials in average housing prices across locations.

To see the effect of an increase in labor demand on each of the variables in the model, equations (5)-(7) can be re-written to express each variable as a function of its own previous values and the shocks:

$$
\begin{aligned}
& n_{i t}-n_{i t-1}=\left(1-\beta \delta-\gamma \theta_{i}\right)\left(n_{i t-1}-n_{i t-2}\right)+\beta x_{i}^{d}+\beta \varepsilon_{i t-1}^{d}+\varepsilon_{i t}^{s}-\varepsilon_{i t-1}^{s}+\gamma \varepsilon_{i t}^{p}-\gamma \varepsilon_{i t-1}^{p} \\
& w_{i t}=\left(1-\beta \delta-\gamma \theta_{i}\right) w_{i t-1}+x_{i}^{d}-\delta x_{i}^{s}+\gamma \delta x_{i}^{p}+\varepsilon_{i t}^{d}+\gamma \theta_{i} \varepsilon_{i t-1}^{d}-\delta \varepsilon_{i t}^{s}+\gamma \delta \varepsilon_{i t-1}^{p}+\gamma \theta_{i} z_{i t-2} \\
& p_{i t}=\left(1-\beta \delta-\gamma \theta_{i}\right) p_{i t-1}+\beta \theta_{i} x_{i}^{d}+\theta_{i} x_{i}^{s}-\beta \delta x_{i}^{p}+\beta \theta_{i} \varepsilon_{i t-1}^{d}+\theta_{i} \varepsilon_{i t}^{s}+\varepsilon_{i t}^{p}-(1+\beta \delta) \varepsilon_{i t-1}^{p}+\beta \theta_{i} z_{i t-2}
\end{aligned}
$$

The immediate impact of an increase in labor demand is an increase in wages as the demand curve shifts up by $\varepsilon_{i t}^{d}$. There is no change in employment or housing prices because migration only depends on lagged values of housing prices and wages. ${ }^{14}$ In the next period, higher relative wages cause workers to migrate into the area. This increase in population creates additional demand for housing, and so housing prices rise as well. The response of housing prices depends on the elasticity of housing supply, as more inelastic areas (higher $\theta_{i}$ ) experience a larger increase in housing prices. Limits on the housing supply also create an additional upward pressure on wages through a lagged effect of the demand shock. Because migration is a function of wages, the effect of the labor demand shock on employment depends on $\beta$. It is useful to note that after the second period, the ratio of the increase in housing prices to the increase in employment in response to a labor demand shock will be $\frac{\beta \theta_{i}}{\beta}=\theta_{i}$. In the empirical analysis below, I will use the relative short-run behavior of these two variables to infer the value of $\theta_{i}$ for metropolitan areas with different degrees of housing supply regulation.

The model shows that the housing supply impacts the labor market through housing prices and the resulting migration response. Higher values of $\theta_{i}$ create more persistence in all

\footnotetext{
${ }^{14}$ In reality, the migration decision is likely to be a function of expected future conditions and not just on past experience. However, if expectations are backward-looking, then estimates of the model parameters will be a function of the true parameters and the discount rate of households (Gallin 2004). Assuming that households in different locations have a similar discount rate, estimates of the relative differences in the elasticity of housing supply will not be affected.
} 
three variables, so that the effect of any shock takes longer to dissipate. ${ }^{15}$ In the long run, migration continues until the ratio of wages to housing prices equals $\frac{\gamma}{\beta}$. The long-run levels of employment, wages and housing prices in response to a 1-unit increase in labor demand are:

$$
\begin{aligned}
& \hat{n}_{i t}=\frac{\beta}{\gamma \theta_{i}+\beta \delta} \\
& \hat{w}_{i t}=\frac{\gamma \theta_{i}}{\gamma \theta_{i}+\beta \delta} \\
& \hat{p}_{i t}=\frac{\beta \theta_{i}}{\gamma \theta_{i}+\beta \delta}
\end{aligned}
$$

These expressions reveal that the elasticity of housing supply has an impact on the longrun levels of all of the variables in the model. In response to a positive labor demand shock, areas with a less responsive housing supply will experience higher wages, higher housing prices, and a lower level of employment. Moreover, these equations emphasize that the effect of a labor demand shock is not determined by differences in average housing prices, but rather by the elasticity of housing supply. The average price in each location is a complex function of the city-specific factors, and thus differences in average prices will reflect differences local amenities and other aspects of both housing demand and supply. In contrast, the responses of wages, prices and employment to a demand shock are not influenced by amenities or other location-specific factors. Consequently, the dynamics of housing and labor markets in response to changes in labor demand will convey more information about differences in the elasticity of housing supply than simply comparing average price differentials across locations.

The model predicts that a labor demand shock can have a lasting impact on wages as long as housing prices are also permanently higher. In contrast, previous research has found that relative wages across local areas tend to converge over time (Barro and Sala-i-Martin 1991, Blanchard and Katz, 1992). In the original model developed by Blanchard and Katz, firms

\footnotetext{
${ }^{15}$ Throughout this analysis, I assume that $\left|1-\beta \delta-\gamma \theta_{i}\right|<1$, so that the effects of a shock will die out over time. In a survey of estimates of the elasticity of labor demand, Hamermesh (1993) concludes that the aggregate elasticity of labor demand is in the range of -.15 to -.75 , which implies that $\delta$, the elasticity of wages with respect to labor supply, is between -.12 and -.6 (see pages 26-29). DiPasquale (1999) reviews the literature on the elasticity of housing supply and concludes that the aggregate housing supply is elastic: most estimates range between 1.5 and 5 . Therefore $\theta$, which is the inverse of the elasticity of housing supply, is likely to be less than 1 for the typical metropolitan area. The magnitudes of $\beta$ and $\gamma$ are more difficult to determine because they are related the parameters of an individual's utility function.
} 
respond to relative wage differentials by relocating to areas with lower wages. After a positive labor demand shock shifts the labor demand curve upward, out-migration of firms creates downward shifts in labor demand until relative wages return to their initial equilibrium. The model presented here rules out this response because wage convergence would mean that relative housing prices must converge as well. Because the position of the housing supply curve is fixed, the only way that housing prices can return to their initial level is if the housing stock (and therefore the level of employment) returns to its initial level as well. Thus, relative wage convergence in this model would imply that an increase in labor demand can have no long-run effect.

To obtain lasting effects on the level of employment in combination with convergence in relative wages and housing prices, the model can be extended so that higher prices lead to entry in the construction industry. In other words, the position of the housing supply curve can be allowed to depend on the relative level of housing prices. In response to high housing prices, construction firms will enter the market causing the housing supply curve to shift out, so that the housing supply is more elastic in the long run than the short-run elasticity implied by $\theta_{i}$. In the long run, an increase in labor demand will have no effect on relative wages or housing prices, but the equilibrium levels of employment and the housing stock will be higher. Although this model has more realistic long-run predictions, I focus on the model without firm entry and exit in either the product or housing markets for simplicity. However, it should be kept in mind that the wage and price differentials predicted by this model are not likely to persist in the very long run.

\section{Section 4: Estimating the Effect of the Housing Supply on Local Labor Markets}

The model discussed in the previous section shows that the effect of an increase in labor demand depends on the elasticity of housing supply. To assess these predictions empirically, I trace out the effect of an increase in labor demand on metropolitan area housing and labor markets. As described in Section 2, I follow Bartik (1991) and calculate shocks to labor demand arising from differences in the industrial composition of metropolitan areas interacted with national shocks to industrial employment growth. To observe the effect of these shocks on employment, wages and housing prices, I estimate the following 3-variable Vector AutoRegression (VAR) based on the reduced-form expressions in equation 8 : 
$Y_{i t}=\left[\begin{array}{c}\Delta n_{i t} \\ w_{i t} \\ p_{i t}\end{array}\right]=B_{1} Y_{i t-1}+B_{2} Y_{i t-2}+B_{1}^{r} Y_{i t-1} r e g_{i}+B_{2}^{r} Y_{i t-2} r e g_{i}+C \hat{\varepsilon}_{i t}^{d}+C^{r} \hat{\varepsilon}_{i t}^{d} r e g_{i}+D_{i}+D_{t}+V_{i t}$

This system of equations expresses the change in the logarithm of employment, the logarithm of wages, and the logarithm of housing prices each as a function of two of its own lags, two lags of the other endogenous variables, and the contemporaneous labor demand shocks $\left(\hat{\varepsilon}_{i t}^{d}\right){ }^{16}$ To examine how labor and housing market dynamics vary with the elasticity of housing supply, all variables are interacted with the index of housing supply regulation. Each equation includes year and metropolitan area fixed effects, and is estimated using annual data from 1980 to 2002. Thus, the results are identified from the behavior of relative wages, employment and housing prices within each metropolitan area over time. This method is more useful than estimating the effects from a single cross-section because locations differ along many unobservable dimensions that can easily confound a cross-sectional comparison of locations. The final sample is a balanced panel comprising a total of 72 metropolitan areas, which includes all of the metropolitan areas with a value of the housing supply regulation index and complete information on housing prices from 1980 to the present.

The initial effects of the labor demand shock on each of the three endogenous variables in the system are shown in Table 4. The coefficient on the demand shock in the employment growth equation is 1.04 , which implies that in the average metropolitan area, there is a strong relationship between increases in labor demand and increases in employment. This result is reassuring because it indicates that the method of calculating labor demand shocks yields accurate predictions of actual increases in labor demand. In the average metropolitan area, an increase in labor demand is also associated with higher wages, but only a small and insignificant change in housing prices.

The interaction terms in the second column show how housing supply regulations alter the responses of employment, wages and housing prices. In areas where the housing supply is more constrained, an increase in labor demand leads to higher housing prices. This effect is accompanied by a higher level of wages and a smaller increase in employment, which is a sign

\footnotetext{
${ }^{16}$ I allow for only two lags of each variable because the time dimension of the panel is relatively short, extending for a total of 22 years. Adding a third lag does not change the results substantially, as the coefficients on the $3^{\text {rd }}$ lags are generally small and insignificantly different from zero.
} 
that migration into these areas is constrained. The fourth row of the table shows the implied estimates of $\theta$, the inverse of the elasticity of housing supply. As shown by the reduced-form equations $8(\mathrm{a})$ and $8(\mathrm{c})$, these estimates can be obtained by taking the ratio of the response of housing prices to a change in demand over the response of employment growth. The results are consistent with a lower elasticity in highly constrained areas, as a 1 standard deviation increase in the housing supply regulation index is associated with an estimate of $\theta$ that is twice as high. However, the standard errors are large that the two estimates are not significantly different from one another.

To examine the long-run impact of housing supply regulations, Figure 5 shows the impulse response functions from the VAR. The solid lines show the response of each endogenous variable to a 1 percent increase in labor demand in an area at the $25^{\text {th }}$ percentile of the housing supply regulation index (equivalent to the index value of Denver, CO). I calculate these long-run effects by setting the response of each variable in the first period equal to the estimated coefficient shown in the first column of Table 4 plus the interaction term multiplied by the value of the index at the $25^{\text {th }}$ percentile (-.69). In the second period the labor demand shock is set equal to zero, but the endogenous variables continue to evolve due to the lagged effects of employment growth, wages and housing prices and the interactions of these lagged variables with the degree of housing supply regulation. While the VAR generates predictions for the levels of wages and housing prices directly, the employment growth prediction is converted to a level by assuming the logarithm of the initial level of employment is zero.

Initially, the shock leads to increases in employment and wages, with only a small change in housing prices. The level of employment rises for the next few years and then declines, converging to a long-run effect of about 1 percent after 15 years. Relative wages decline more gradually, taking about 25 years to return to their initial level. In the first few years following the employment shock, housing prices rise by about 1.8 percent. This increase is due to a positive effect of lagged employment growth on housing prices. Since the housing market is not perfectly elastic, the inflow of migration that was generated by the initial the demand shock creates excess housing demand, causing housing prices to rise. It is interesting to note that the effect of the demand shock is actually larger on housing prices than on wages, so that the real value of wages falls in the first few years following the shock. Another interesting result is that house prices fall below their initial level before converging to the long-run equilibrium. This dip 
is related to a strong degree of mean-reversion in the level of housing prices, which is captured by a negative coefficient estimate on second lag of housing prices in the house price equation. As falling employment causes house prices to decline, high past values of house prices create an increasingly large drag on current prices. This force creates oscillation of prices as they converge back to their initial equilibrium level.

The dashed lines in the figure show the impulse response functions for an area at the $75^{\text {th }}$ percentile of the housing supply regulation index (equivalent to Newark, NJ). As predicted by the model, the demand shock has a smaller impact on employment and a larger impact on wages and housing prices. After the large, initial effect on housing prices, prices continue to rise for the next 4 years as labor migration increases the demand for housing. Wages are also higher and this increase persists for a long time. Finally, changes in employment are smaller in areas with an inelastic housing market, leading to a lower level of employment. The long-run impact of a 1 percent demand shock results in only a 0.9 percent increase in employment, instead of the 1 percent increase found in less constrained areas. ${ }^{17}$

The effects documented in this figure rely on the assumption that the labor demand shocks are uncorrelated with the error term in each of the three estimating equations. However, these estimates will be biased if the effect of a demand shock is smaller in places with more regulation for reasons other than housing supply constraints. For example, if places with a high degree of housing market regulation also have a stronger regulatory environment more generally, the negative impact of housing supply regulations on employment will be overstated. On the other hand, factors like weather might cause a labor demand shock to lead to a larger employment response in places where it is more pleasant to live. If this geographic amenity is correlated with a stronger degree of housing supply regulation, the estimated employment effects will be biased downward. A third source of concern is the age of the metropolitan area. If firms in older cities have a less productive capital stock, they will hire fewer workers than firms in the same industry that are located in newer cities. In this case, the measured demand shocks will overstate the actual amount of labor demand in older cities. If there are also more housing supply regulations in older cities, then the estimated effect of regulation will be biased.

\footnotetext{
${ }^{17}$ Using a bootstrap technique to calculate confidence intervals around these estimates, 90 percent of the simulated estimates fall in the range of $[.83,1.23]$ for an elastic location and $[.68,1.10]$ for the inelastic location. Thus, these long-run employment effects are not significantly different from one another.
} 
To address these issues, I re-estimate the VAR including interactions of observable measures of these omitted factors with the labor demand shock and with all of the endogenous variables in the model. These interactions allow the labor and housing market dynamics in each location to vary with each of the new control variables as well as by the degree of housing supply regulation. The four variables I consider are an index of the regulatory environment at the state level, the extent of unionization in the metropolitan area (also as a measure of regulation in the labor market), the logarithm of January temperature, and the age of the metropolitan area. ${ }^{18}$ As before, I estimate the impulse response functions in response to a 1 percent increase in labor demand for metropolitan areas at the $25^{\text {th }}$ and $75^{\text {th }}$ percentiles of the distribution of housing supply regulations. Each control variable is normalized to have a mean of zero, so the effect of housing supply regulation can be interpreted as occurring at the mean of these other variables.

The long-run level of employment after 20 years is reported in the first two columns of Table 5. In each case the estimated impact of housing supply regulation is essentially unchanged, as employment growth is about 0.1 percentage point lower in areas that are relatively constrained. The third and fourth columns report the long run impact on employment in areas at the $25^{\text {th }}$ and $75^{\text {th }}$ percentiles of each of the other control variables. For example, an area at the $75^{\text {th }}$ percentile of the state regulatory index has a 0.11 percent smaller employment response than an area at the $25^{\text {th }}$ percentile. ${ }^{19}$

Another source of concern is that the index of housing supply regulation might be correlated with geographic factors that make the supply of housing more inelastic in some locations relative to others. Therefore, the final two rows of Table 5 show the effect of controlling for interactions with two variables that proxy for the supply of land: the share of total area taken up by water, and the number of housing units per square kilometer in 1980. Although these variables also appear to have a negative impact on employment, the estimated effect of regulation is unchanged. Therefore, the effects of regulation shown in Table 4 and Figure 5 do not appear to be driven by an unobserved correlation with other omitted factors.

\footnotetext{
${ }^{18}$ Because including each variable entails estimating seven new parameters in each equation, I include these factors in the VAR one at a time. Each variable is constant over time, so the level effect is subsumed in the metropolitan area fixed effects. See the Appendix for definitions and sources of these variables.

${ }^{19}$ Although the majority of these estimates go in the expected direction, warmer temperatures and less unionization appear to lead to lower employment in the long run. However, the short-run effects of these variables are more sensible, as employment is substantially higher in warmer and less unionized places in the first 11 years after the shock.
} 
So far, this analysis has focused on comparing the effects of housing supply regulation at two different values of the regulatory index. Because there is substantial heterogeneity in the elasticity of housing supply, is also useful to consider the entire range of the housing supply regulation index. To do so, I use the VAR results from Table 4 to calculate impulse response functions at each of the observed values of the index and examine the predicted level of employment after a 20-year period. The distribution of these values is shown in Figure 6. The response to a 1 percent increase in labor demand in many of the metropolitan areas is close to 1 percent, which emphasizes that the housing supply in many locations is fairly elastic, at least in the long run. However, the distribution is skewed with a significant number of metropolitan areas in the left-hand tail. For example in New York, which was estimated to have the most inelastic housing supply, a 1 percent increase in labor demand leads to only a 0.65 percent increase in employment. ${ }^{20}$ In more than 10 percent of the metropolitan areas, the long-run employment response is less than 0.8 percent. These results show clearly that in some parts of the United States, employment growth can be severely limited by constraints on residential construction.

\section{Section 5: Effects on Aggregate Output}

The labor market dynamics described above demonstrate that employment growth is constrained in areas with high amounts of housing supply regulation. By preventing people from moving to areas where the marginal product of labor is highest, these regulations mean that labor will not be allocated efficiently across locations. To assess the magnitude of this effect, it is useful to consider an economy made up of two cities, each with the same downward-sloping demand for labor: $w_{i t}=a n_{i t}+\varepsilon_{i t}{ }^{21}$ A productivity shock that raises the demand curve in City A by $w_{A} \varepsilon^{d}$ will cause people to move from City B to City A until real wages are equalized across locations. Because productivity is higher in City A, production will increase by more in City A than it falls in City B, and so aggregate output will grow. The magnitude of this increase is equal to the number of migrants times the difference in the marginal product of labor between the two

\footnotetext{
${ }^{20}$ The 90 percent confidence band encompasses the interval $[.42, .96]$, so this estimate is significantly less than 1 .

${ }^{21}$ This exercise is based on the approach used by Borjas (1995) to evaluate the effect of immigrants on aggregate output.
} 
areas. Assuming that wages were initially equal in the two locations and that the demand curve has a constant slope $a=\frac{\Delta w}{\Delta N}$, the aggregate gain from migration can be written as:

$$
\begin{aligned}
\text { Gain } & =\left(N_{A}^{\prime}-N_{A}\right)\left(w_{A}^{\prime}-w_{B}\right) \\
& =\left(N_{A}^{\prime}-N_{A}\right)\left[w_{A}\left(1+\varepsilon^{d}\right)-\frac{\Delta w}{\Delta N}\left(N_{A}^{\prime}-N_{A}\right)-w_{A}\right] \\
& =\left(N_{A}^{\prime}-N_{A}\right)\left[w_{A} \varepsilon^{d}-\left(\frac{\Delta w}{\Delta N} \frac{N_{A}}{w_{A}\left(1+\varepsilon^{d}\right)}\right) \frac{w_{A}\left(1+\varepsilon^{d}\right)}{N_{A}}\left(N_{A}^{\prime}-N_{A}\right)\right] \\
& =\frac{N_{A}^{\prime}-N_{A}}{N_{A}} N_{A} w_{A} \varepsilon^{d}+\delta w_{A}\left(1+\varepsilon^{d}\right) N_{A}\left(\frac{N_{A}^{\prime}-N_{A}}{N_{A}}\right)^{2}
\end{aligned}
$$

where $\delta$ is the elasticity of factor price for labor $\left(\frac{\partial w / w}{\partial N / N}\right)$ evaluated at the point $\left[\mathrm{N}_{\mathrm{A}}\right.$, $\left.w_{A}\left(1+\varepsilon^{d}\right)\right]$, which is the point corresponding to equilibrium employment and wages after the productivity shock but before any migration has occurred. In a comprehensive survey of the literature, Hamermesh (1993) concludes that the aggregate elasticity of labor demand is in the range of -.15 to -.75. Because agglomeration effects may cause decreasing returns to set in at a slower rate in cities (Ciccone and Hall 1996, Glaeser and Mare 2001), I consider an estimate at the high end of this range. In the case of two inputs to production, the elasticity of factor price for labor is equal to $\left(1-\mathrm{s}_{\mathrm{L}}\right)^{2} / \eta$, where $\eta$ is the elasticity of labor demand and $\mathrm{s}_{\mathrm{L}}$ is labor's share of income (see Hammermesh 1993, pages 26-29). Assuming $\mathrm{s}_{\mathrm{L}}=.7$ and $\eta=-.75$ yields an estimate of $\delta=-.12$.

The results in the previous section suggest that in locations where housing supply constraints are less severe, a 1 percent productivity shock should lead to about a 1 percent increase in employment. Assuming that the typical metropolitan area has about 500,000 workers and an average wage of $\$ 30,000,{ }^{22}$ the increase in aggregate output generated by migration from City B to City A would be about $\$ 1.32$ million. In contrast, metropolitan areas with a high degree of housing supply regulation experience only a 0.8 percent increase in employment in response to the same demand shock. In this case, aggregate output would only increase by about $\$ 1.08$ million. Thus, housing supply constraints have the effect of lowering the gains from migration by about 18 percent in these locations. If housing supply restrictions were as severe as

\footnotetext{
${ }^{22}$ These figures reflect the average value in 2000 across all of the metropolitan areas in my sample.
} 
in New York, employment would only increase by 0.65 percent. This amount of migration would lead to an aggregate gain of only $\$ 0.9$ million, which is 32 percent lower than it would be given the degree of regulation in the average metropolitan area.

Although stylized, this model highlights the role of labor migration as a means of adjustment to changes in local labor demand. Housing supply restrictions constrain these migration flows, leading to a lower level of total output. ${ }^{23}$ Because land use regulations are established at the local level, they are usually designed to satisfy local constituents. Consequently, the political economy of land-use regulations may encourage local policymakers to ignore the broader consequences of these regulations in favor of the perceived benefits to local residents.

\section{Section 6: Conclusion}

Housing supply regulations have a substantial impact on housing and labor market dynamics in metropolitan areas across the United States. By raising the marginal cost of construction, land use restrictions and other government regulations lower the elasticity of housing supply. Thus, these regulations change the geographic distribution of relative housing prices and alter the pattern of labor migration. As a result, employment growth is lower in places where the housing supply is more constrained.

Indeed, metropolitan areas with constrained housing markets respond differently to a labor demand shock than less restricted locations. Raising the degree of housing supply regulation by one standard deviation results in 17 percent less residential construction and twice as large growth in housing prices in response to an increase in labor demand. Moreover, housing supply regulations have a lasting effect on metropolitan area employment. In the long run, an increase in labor demand results in 20 percent less employment in metropolitan areas with a low elasticity of housing supply. These results demonstrate that the interaction between the housing supply and local labor markets is an important determinant of regional patterns of employment growth.

As places with a large degree of regulation experience rising housing prices, these restrictions may also have an impact on the composition of the population within metropolitan

\footnotetext{
${ }^{23}$ The total effect on economic growth will be smaller if there are negative externalities associated with building additional housing. On the other hand, the total impact will be larger if there are agglomeration effects that raise productivity due to a larger workforce.
} 
areas. Because young people and minorities have a higher propensity to move (U.S. Census Bureau 2004), areas with many housing supply constraints may end up with a smaller fraction of people in these groups. Furthermore, high housing prices may mean that only rich people can afford to move into an area and that poorer people are forced out, leading to higher income inequality within the area (Gyourko, Mayer and Sinai 2004). As housing prices influence the types of people who live in a location, changes in the availability of workers with different levels of skills may also lead to changes in the industrial composition of local firms.

Although this paper has focused on their negative consequences, policies that restrict the expansion of the housing supply are not without benefits. By enforcing quality standards for residential housing units and reducing the negative externalities associated with crowding and undesirable land uses, these regulations can make some local residents better off. A large literature has examined both the positive and negative effects of housing supply restrictions on housing markets. However, the implications of these policies for local labor markets have been largely overlooked. The results in this paper show that the costs of housing supply regulations will be underestimated if the effects on the labor market are not taken into account. Therefore, a complete discussion of land use policy should include, not only the impact on housing markets, but the implications for labor markets and employment growth as well. 


\section{References}

American Institute of Planners. 1976. Survey of State Land Use Planning Activity. Washington, DC: Department of Housing and Urban Development.

Barro, Robert and Xavier Sala-i-Martin. 1991. "Convergence Across States and Regions." Brookings Papers on Economic Activity 1991(1): 107-182.

Bartik, Timothy. 1991. Who Benefits from State and Local Economic Development Policies? Kalamazoo: W.E. Upjohn Institute for Employment Research.

Blanchard, Olivier and Lawrence Katz. 1992. "Regional Evolutions." Brookings Papers on Economic Activity 1992(1): 1-75.

Bogue, Donald J. 1953. Population Growth in Standard Metropolitan Areas 1900-1950. Washington, DC: Housing and Home Finance Agency.

Borjas, George J. 1995. "The Economic Benefits from Immigration." Journal of Economic Perspectives 9(2): 3-22.

Bover, Olympia, John Muellbauer and Anthony Murphy. 1989. "Housing, Wages and UK Labor Markets." Oxford Bulletin of Economics \& Statistics 51(2): 97-136.

Byers, John, Robert McCormick and Bruce Yandle. 1999. "Economic Freedom in America's 50 States." Manuscript. http://sixmile.clemson.edu/freedom/index.htm

Capozza, Dennis, Patric Hendershott, Charlotte Mack and Christopher J. Mayer. 2002. "Determinants of Real House Price Dynamics." NBER Working Paper 9262.

Case, Karl E. 1991. "The Real Estate Cycle and the Economy: Consequences of the Massachusetts Boom of 1984-97." New England Economic Review (Sept/Oct.): 37-46.

Case, Karl E. and Robert J. Shiller. 1989. "The Efficiency of the Market for Single-Family Homes." American Economic Review 79(1): 125-137.

Ciccone, Antonio and Robert Hall. 1996. "Productivity and the Density of Economic Activity." American Economic Review 6(1): 54-70.

Clark, Terry Nichols and Edward G. Goetz. 1994. "The Antigrowth Machine." In Urban Innovation: Creative Strategies for Turbulent Times, edited by Terry Nichols Clark. Thousand Oaks, CA: Sage Publications.

DiPasquale, Denise. 1999. "Why Don't We Know More about Housing Supply?” Journal of Real Estate Finance and Economics 18(1): 9-23. 
Evenson, Bengte. 2003 "Understanding House Price Volatility: Measuring and Explaining the Supply Side of Metropolitan Area Housing Markets.” Manuscript (April).

Fischel, William. 1985. The Economics of Zoning Laws. Baltimore, MD: The Johns Hopkins University Press.

Gabriel, Stuart, Janice Shack-Marquez and William Wascher. 1993. "The Effects of Regional House Price and Labor Market Variability on Interregional Migration: Evidence from the 1980s." In Housing Markets and Residential Mobility, edited by G. T. Kingsley and M. Turner. Washington, DC: The Urban Institute Press.

Gallin, Joshua Hojvat. 2004 "Migration and Labor Market Dynamics." Journal of Labor Economics 22 (January) 1-21.

Glaeser, Edward and Joseph Gyourko. 2001. "Durable Housing and Urban Decline." NBER Working Paper 8598.

Glaeser, Edward, Joseph Gyourko and Raven E. Saks. 2004. "Urban Growth and Housing Supply.” Manuscript (July).

Glaeser, Edward and David Mare. 2001. "Cities and Skills.” Journal of Labor Economics 19(2): 316-342.

Green, Richard K., Stephen Malpezzi and Stephen K. Mayo. 1999. "Metropolitan-Specific Estimates of the Price Elasticity of Supply of Housing, and their Sources." Manuscript (December).

Gyourko, Joseph, Christopher J. Mayer and Todd Sinai. 2004. "Superstar Cities.” Manuscript (July).

Hamermesh, Daniel. 1993. Labor Demand. Princeton, NJ: Princeton University Press.

Hwang, Min and John Quigley. (2004) "Economic Fundamentals in Local Housing Markets: Evidence from U.S. Metropolitan Regions.” Manuscript (February).

Johnes, Geraint and Thomas Hyclak. 1999. "House Prices and Regional Labor Markets." Annals of Regional Science 33: 33-49.

Jud, G. Donald and Daniel T. Winkler. 2002. "The Dynamics of Metropolitan Housing Prices." Journal of Real Estate Research 23(Jan-April): 29-45.

Linneman, Peter, Anita Summers, Nancy Brooks, and Henry Buist. 1990. "The State of Local Growth Management.” Wharton Real Estate Center Working Paper 81.

Malpezzi, Stephen. 1996. "Housing Prices, Externalities and Regulation in US Metropolitan Areas." Journal of Housing Research 7: 209-241. 
Mayer, Christopher and C. Tsuriel Somerville. 2000. "Land Use Regulation and New Construction.” Regional Science and Urban Economics 30: 639-662.

Nerlove, Marc. 1971. "Further Evidence on the Estimation of Dynamic Economic Relations from a Time Series of Cross Sections." Econometrica 39: 359-382.

Nickell, Stephen. 1981. "Biases in Dynamic Models with Fixed Effects.” Econometrica 49: 1417-1426.

Saks, Raven E. 2004. "Housing Supply Restrictions Across the United States." Wharton Real Estate Review (Fall).

Segal, David and Philip Srinivasan. 1985. "The Impact of Suburban Growth Restrictions on US Housing Price Inflation, 1975-1978." Urban Geography 6(1):1-26.

Seidel, Stephen. 1978. Housing Costs and Government Regulations. New Brunswick, NJ: The Center for Urban Policy Research.

Topel, Robert. 1986. “Local Labor Markets.” Journal of Political Economy. 94(3): 111-143.

U.S. Census Bureau. 2004. “Geographic Mobility: 2002-2003.” Current Population Reports (March). 
Table 1

Survey Measures of Housing Supply Regulation

\begin{tabular}{lcccc}
\hline Source & $\begin{array}{c}\text { Time } \\
\text { Period }\end{array}$ & $\begin{array}{c}\text { \# of survey } \\
\text { questions }\end{array}$ & $\begin{array}{c}\text { Type of } \\
\text { jurisdiction }\end{array}$ & $\begin{array}{c}\text { \# of } \\
\text { MSAs }\end{array}$ \\
\hline Wharton Urban Decentralization Project & $1988-90$ & 8 & $\begin{array}{c}\text { Metropolitan } \\
\text { Areas } \\
\text { Cities }\end{array}$ & 60 \\
$\begin{array}{l}\text { International City Management Association } \\
\text { Fiscal Austerity and Urban Innovation }\end{array}$ & 1984 & 4 & 155 \\
$\begin{array}{l}\text { Project } \\
\text { Regional Council of Governments }\end{array}$ & $1983-84$ & 1 & Cities & 62 \\
National Register of Historic Places & $\begin{array}{c}\text { Prior to } \\
1980\end{array}$ & 2 & $\begin{array}{c}\text { Areas } \\
\text { Counties }\end{array}$ & 318 \\
American Institute of Planners & 1976 & 8 & States & 318 \\
\hline
\end{tabular}

Table 2

Ten Most and Least Regulated Metropolitan Areas

\begin{tabular}{|c|c|c|c|}
\hline \multicolumn{2}{|r|}{ Most Regulated } & \multicolumn{2}{|r|}{ Least Regulated } \\
\hline $\begin{array}{l}\text { Index } \\
\text { value }\end{array}$ & Name & $\begin{array}{l}\text { Index } \\
\text { value }\end{array}$ & Name \\
\hline 2.21 & New York, NY & -2.40 & Bloomington-Normal, IL \\
\hline 2.10 & San Francisco, CA & -1.96 & Buffalo-Niagara Falls, NY \\
\hline 1.89 & Sacramento, CA & -1.65 & Nashville, TN \\
\hline 1.84 & Charleston-North Charleston, SC & -1.50 & Owensboro, KY \\
\hline 1.73 & Riverside-San Bernardino, CA & -1.48 & Joplin, MO \\
\hline 1.65 & San Jose, CA & -1.37 & Pueblo, CO \\
\hline 1.60 & San Diego, CA & -1.36 & Champaign-Urbana, IL \\
\hline 1.51 & Santa Barbara-Santa Maria-Lompoc, CA & -1.32 & Oklahoma City, OK \\
\hline 1.48 & Seattle-Bellevue-Everett, WA & -1.26 & Dayton-Springfield, $\mathrm{OH}$ \\
\hline 1.23 & Gary, IN & -1.23 & Richmond-Petersburg, VA \\
\hline
\end{tabular}

Note. The index of housing supply regulation is calculated by combining information from each of the sources listed in Table 1. The index is scaled to have a mean of 0 , and a standard deviation of 1 and is increasing in the degree of regulation. See the Appendix for details. 
Table 3

\section{Effects of Demand Shocks and Housing Supply Regulation on Metropolitan Area Housing Markets}

\begin{tabular}{|c|c|c|c|c|c|c|}
\hline & \multicolumn{3}{|c|}{$\begin{array}{c}\text { Dependent variable: } \\
\text { Percent Change in Housing Stock }\end{array}$} & \multicolumn{3}{|c|}{$\begin{array}{c}\text { Dependent variable: } \\
\text { Percent Change in Housing Prices }\end{array}$} \\
\hline Demand shock & $\begin{array}{l}.254^{* *} \\
(.096)\end{array}$ & $\begin{array}{l}.345^{* *} \\
(.107)\end{array}$ & $\begin{array}{l}.162 * * \\
(.056)\end{array}$ & $\begin{array}{l}.807 \\
(.458)\end{array}$ & $\begin{array}{l}.252 \\
(.642)\end{array}$ & $\begin{array}{l}.386 \\
(.542)\end{array}$ \\
\hline Demand•regulation & $\begin{array}{l}-.027 * \\
(.016)\end{array}$ & $\begin{array}{l}-.063 * * \\
(.030)\end{array}$ & $\begin{array}{l}-.015 \\
(.021)\end{array}$ & $\begin{array}{l}.120 \\
(.099)\end{array}$ & $\begin{array}{l}.238 \\
(.147)\end{array}$ & $\begin{array}{l}.359 * * \\
(.109)\end{array}$ \\
\hline Negative shock & & $\begin{array}{l}.003 * * \\
(.001)\end{array}$ & $\begin{array}{l}.002^{* *} \\
(.001)\end{array}$ & & $\begin{array}{l}.015 * \\
(.009)\end{array}$ & $\begin{array}{l}.012 \\
(.009)\end{array}$ \\
\hline $\begin{array}{l}\text { Negative shock• } \\
\text { regulation }\end{array}$ & & $\begin{array}{l}-.001 \\
(.001)\end{array}$ & $\begin{array}{l}-.001 \\
(.001)\end{array}$ & & $\begin{array}{l}.011^{* *} \\
(.005)\end{array}$ & $\begin{array}{l}-.0001 \\
(.0052)\end{array}$ \\
\hline $\begin{array}{l}\text { Demand •negative } \\
\text { shock }\end{array}$ & & $\begin{array}{l}-.159 * \\
(.091)\end{array}$ & $\begin{array}{l}-.120 \\
(.091)\end{array}$ & & $\begin{array}{l}1.895^{* *} \\
(.799)\end{array}$ & $\begin{array}{l}1.033 \\
(.785)\end{array}$ \\
\hline $\begin{array}{l}\text { Demand•regulation• } \\
\text { negative shock }\end{array}$ & & $\begin{array}{l}.125 \\
(.076)\end{array}$ & $\begin{array}{l}.034 \\
(.050)\end{array}$ & & $\begin{array}{l}.248 \\
(.260)\end{array}$ & $\begin{array}{l}-.338 \\
(.270)\end{array}$ \\
\hline $\begin{array}{l}\text { Lagged dependent } \\
\text { variable }\end{array}$ & & & $\begin{array}{l}.741^{* *} \\
(.025)\end{array}$ & & & $\begin{array}{l}.596^{* *} \\
(.034)\end{array}$ \\
\hline $\begin{array}{l}\text { Lagged dependent } \\
\text { variable•regulation }\end{array}$ & & & $\begin{array}{l}.053 * * \\
(.019)\end{array}$ & & & $\begin{array}{l}.058 * * \\
(.019)\end{array}$ \\
\hline Year fixed effects & yes & yes & yes & yes & yes & yes \\
\hline MSA fixed effects & yes & yes & yes & yes & yes & yes \\
\hline \# MSAs & 58 & 58 & 58 & 58 & 58 & 58 \\
\hline \# Observations & 1276 & 1276 & 1276 & 1276 & 1276 & 1276 \\
\hline
\end{tabular}

Note. Each column shows the coefficients from a separate OLS regression where the dependent variable is changes in the housing stock (left panel) or changes in housing prices (right panel). A negative shock is defined as a demand shock $<0$. Regulation is the combined index of housing supply regulation described in the text. Standard errors are in parentheses and are clustered by state. ${ }^{* *}$ denotes significance at the $5 \%$ level and $*$ denotes significance at the $10 \%$ level. 
Table 4

Initial Effects of a 1 Percent Demand Shock on Employment, Wages and Housing Prices

\begin{tabular}{|c|c|c|}
\hline & $\begin{array}{l}\text { Demand } \\
\text { Shock }\end{array}$ & $\begin{array}{l}\text { Demand Shock• } \\
\text { Regulation }\end{array}$ \\
\hline Employment Growth & $\begin{array}{l}1.04 * * \\
(.20)\end{array}$ & $\begin{array}{l}-.06^{* *} \\
(.02)\end{array}$ \\
\hline Ln(Wage) & $\begin{array}{l}.68^{* *} \\
(.11)\end{array}$ & $\begin{array}{l}.07^{* *} \\
(.03)\end{array}$ \\
\hline Ln(Housing Price) & $\begin{array}{l}.13 \\
(.22)\end{array}$ & $\begin{array}{l}.15 \\
(.10)\end{array}$ \\
\hline Implied $\theta=\frac{1}{\text { elasticity of housing supply }}$ & $\begin{array}{l}.13 \\
(.20)\end{array}$ & $\begin{array}{l}.29 \\
(.22)\end{array}$ \\
\hline $\begin{array}{l}\mathrm{Chi}^{2} \text { test that } \theta \text { is equal across } \\
\text { areas }\end{array}$ & $\begin{array}{l}2.14 \\
(.14)\end{array}$ & \\
\hline \multicolumn{3}{|c|}{$\begin{array}{l}\text { Note. Cells in the top three rows show the coefficients on the labor demand shock } \\
\text { from the VAR described in the text, with standard errors in parentheses (clustered by } \\
\text { state). Regressions are estimated using annual data from } 1980 \text { to } 2002 \text { and include } \\
\text { time and MSA fixed effects. In the first column, } \theta \text { is calculated as the ratio of the } \\
\text { third row to the first row. The second column shows the ratio of the sum of the base } \\
\text { effect and interaction term in the third row to the same sum in the first row. The } \\
\text { final row shows the Chi }{ }^{2} \text { statistic testing that the two estimates of } \theta \text { are equal, with p- } \\
\text { value in parentheses. ** denotes significance at the } 5 \% \text { level and * denotes } \\
\text { significance at the } 10 \% \text { level. }\end{array}$} \\
\hline
\end{tabular}


Table 5

Long-Run Employment Responses to a 1 Percent Increase in Labor Demand Controlling for Other Factors

\begin{tabular}{|c|c|c|c|c|}
\hline & \multicolumn{2}{|c|}{$\begin{array}{l}\text { Housing Supply } \\
\text { Regulation }\end{array}$} & \multicolumn{2}{|c|}{$\begin{array}{l}\text { Control Variable } \\
\text { (named in row) }\end{array}$} \\
\hline & $\begin{array}{c}25^{\text {th }} \\
\text { percentile }\end{array}$ & $\begin{array}{c}75^{\text {th }} \\
\text { percentile }\end{array}$ & $\begin{array}{c}25^{\text {th }} \\
\text { percentile }\end{array}$ & $\begin{array}{c}75^{\text {th }} \\
\text { percentile }\end{array}$ \\
\hline \multicolumn{5}{|l|}{ Control variable: } \\
\hline January temperature & .90 & .79 & .88 & .80 \\
\hline MSA age & .87 & .71 & .81 & .79 \\
\hline Unionization & 1.02 & .88 & .92 & .97 \\
\hline State regulation & 1.00 & .93 & 1.03 & .92 \\
\hline Fraction water & 1.07 & .97 & 1.05 & 1.02 \\
\hline Housing density & .98 & .88 & .94 & .84 \\
\hline \multicolumn{5}{|c|}{$\begin{array}{l}\text { Note. Each cell shows the level of employment after } 20 \text { years in response to a } 1 \text { percent } \\
\text { increase in labor demand. Each row is from a separate VAR as described in the text. In } \\
\text { each VAR, both the index of housing supply regulation and the control variable named in } \\
\text { the row are fully interacted with the labor demand shock and all lagged endogenous } \\
\text { variables. Impulse response functions are calculated at the } 25^{\text {th }} \text { and } 75^{\text {th }} \text { percentiles of } \\
\text { housing supply regulation, and then at the } 25^{\text {th }} \text { and } 75^{\text {th }} \text { percentiles of the control variable } \\
\text { named in each row. Variable definitions can be found in the Appendix. }\end{array}$} \\
\hline
\end{tabular}


Figure 1

Long-Run Changes in Employment and the Housing Stock in Metropolitan Areas

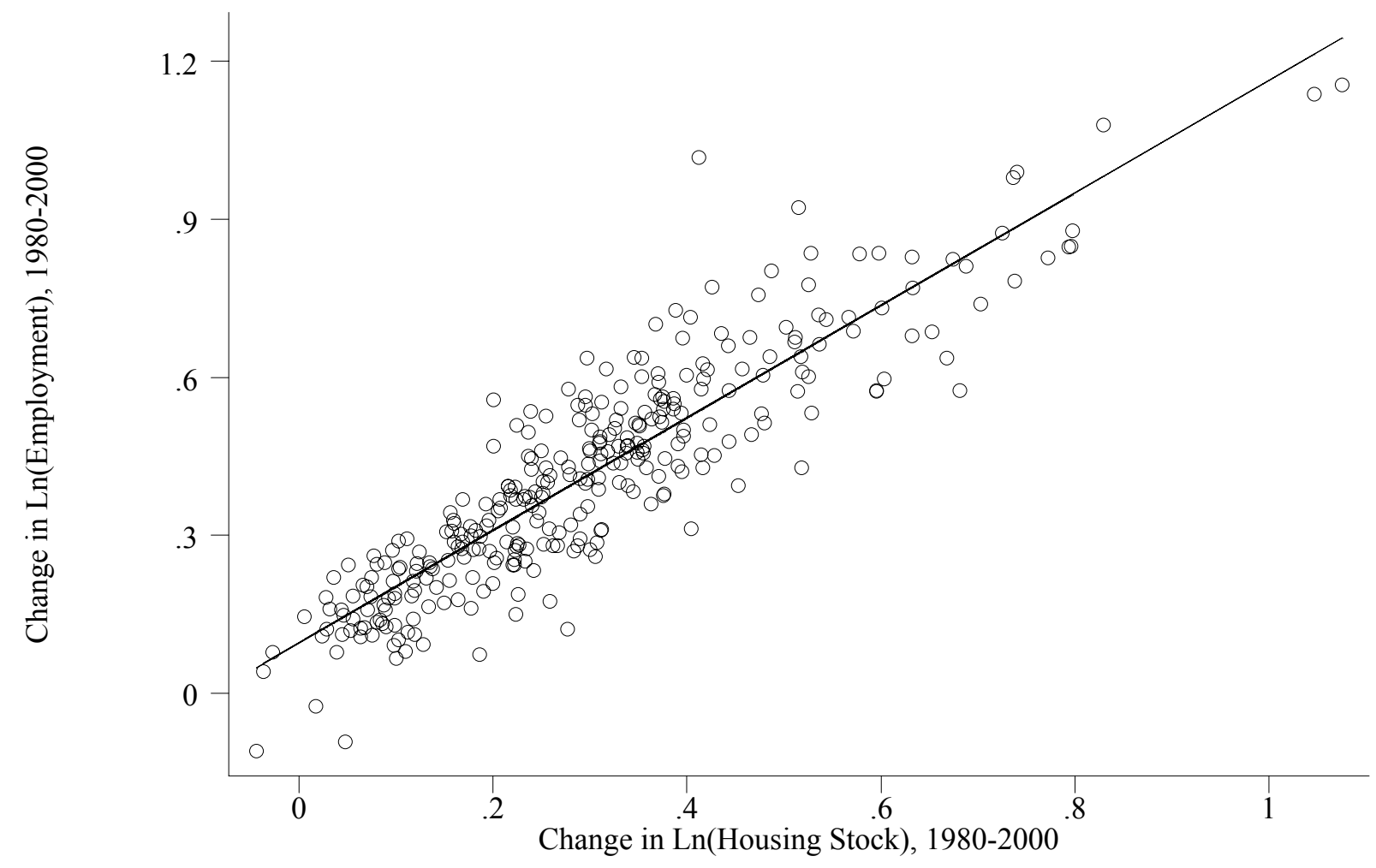


Figure 2

Housing Supply Regulation and Housing Price Growth, 1980-2000
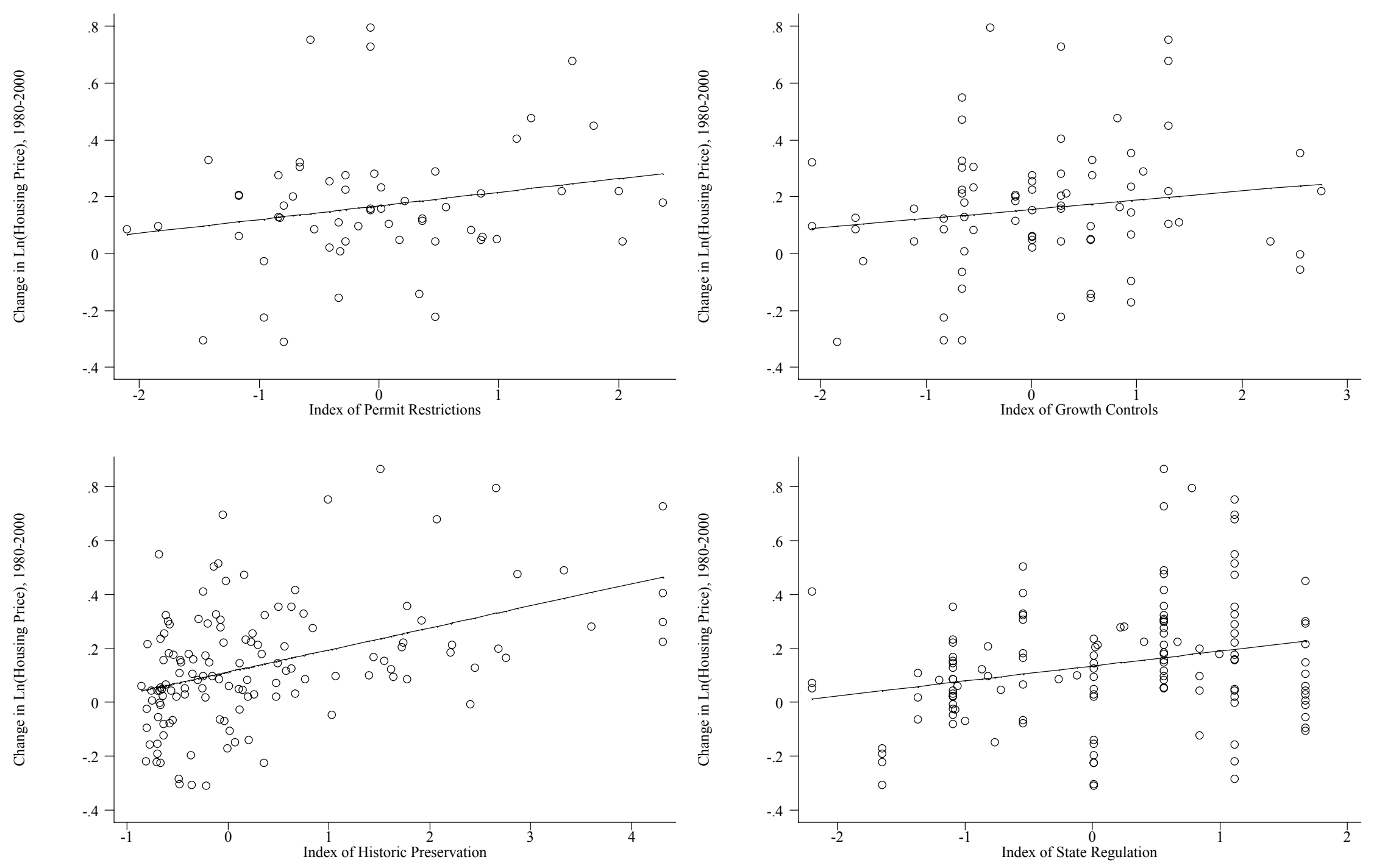
Figure 3

Housing Supply Regulation and Growth in the Housing Stock, 1980-2000
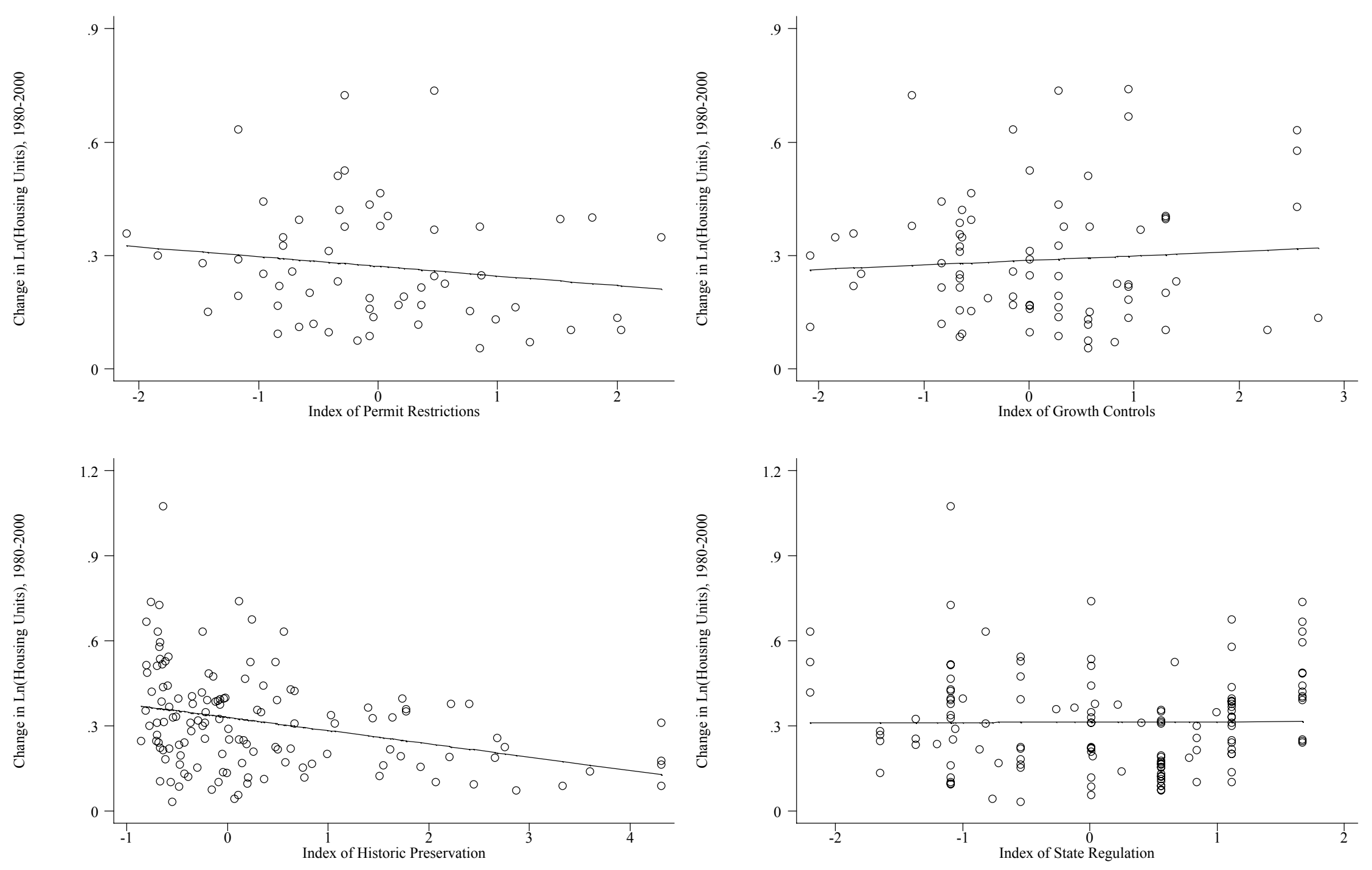
Figure 4

Combined Index of Housing Supply Regulation and

Growth in Growth in Housing Prices and Quantities, 1980-2000

Change in Housing Prices

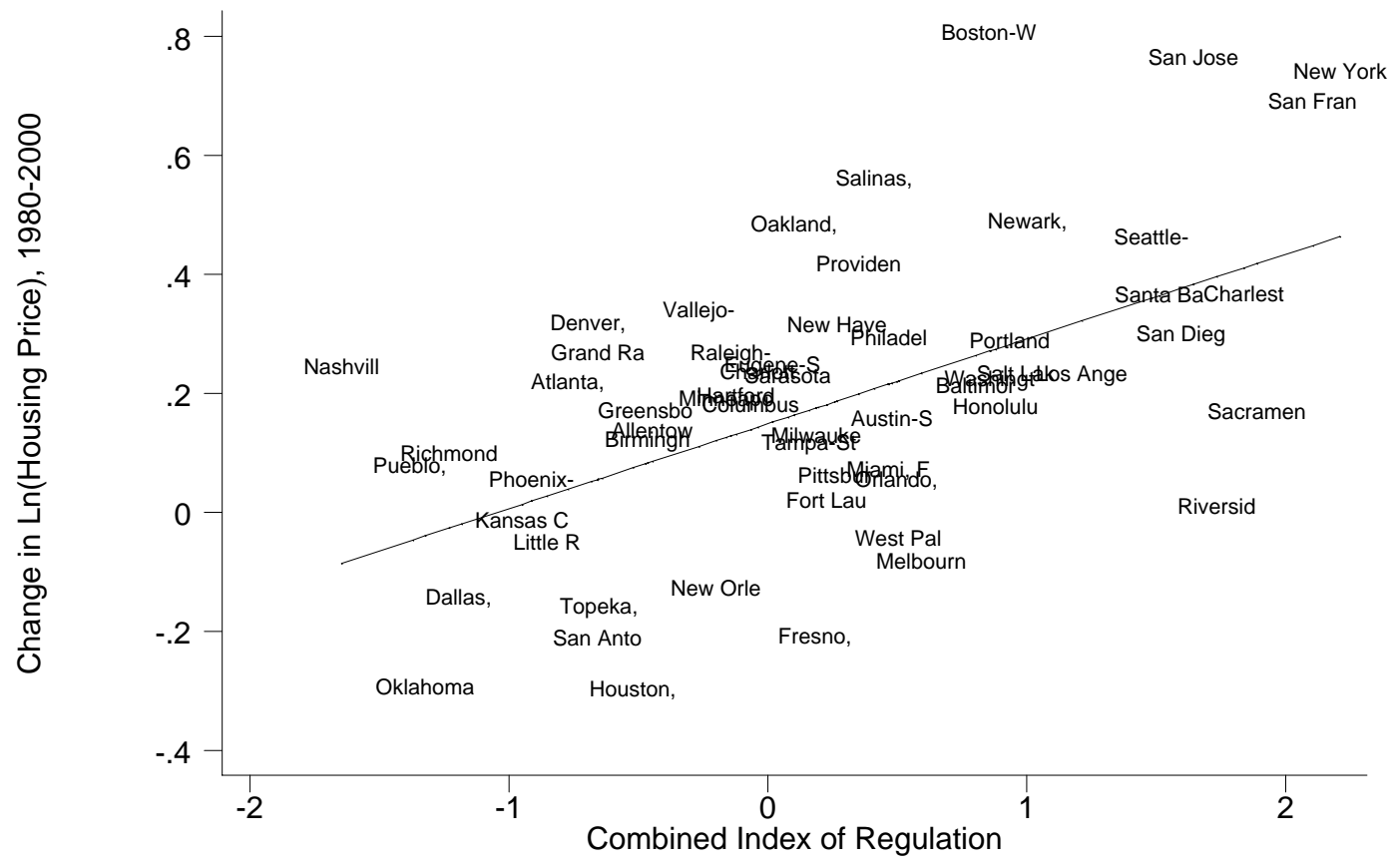

Change in Housing Stock

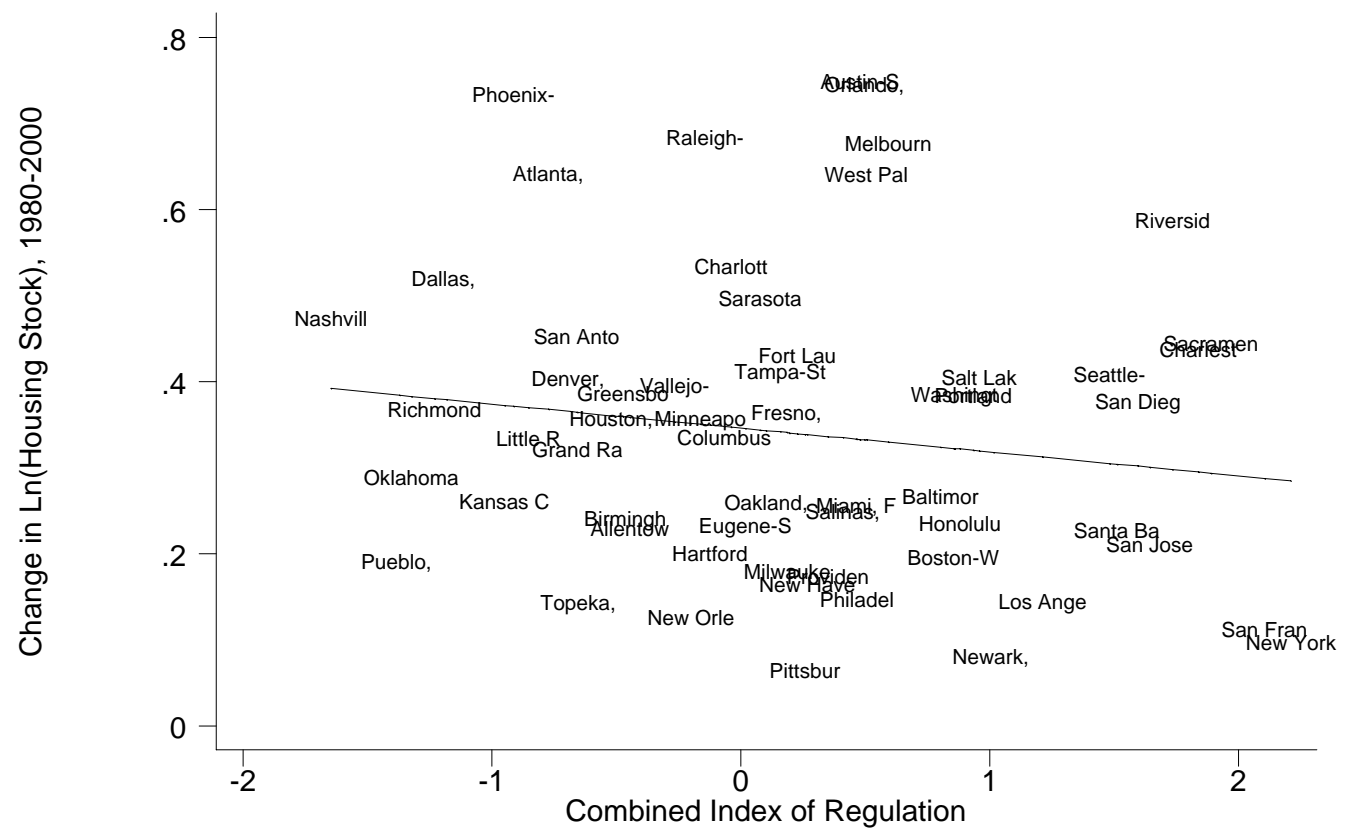


Figure 5

Long-Run Response to a 1 Percent Increase in Labor Demand Evaluated at the $25^{\text {th }}$ and $75^{\text {th }}$ Percentiles of the Housing Supply Regulation Index
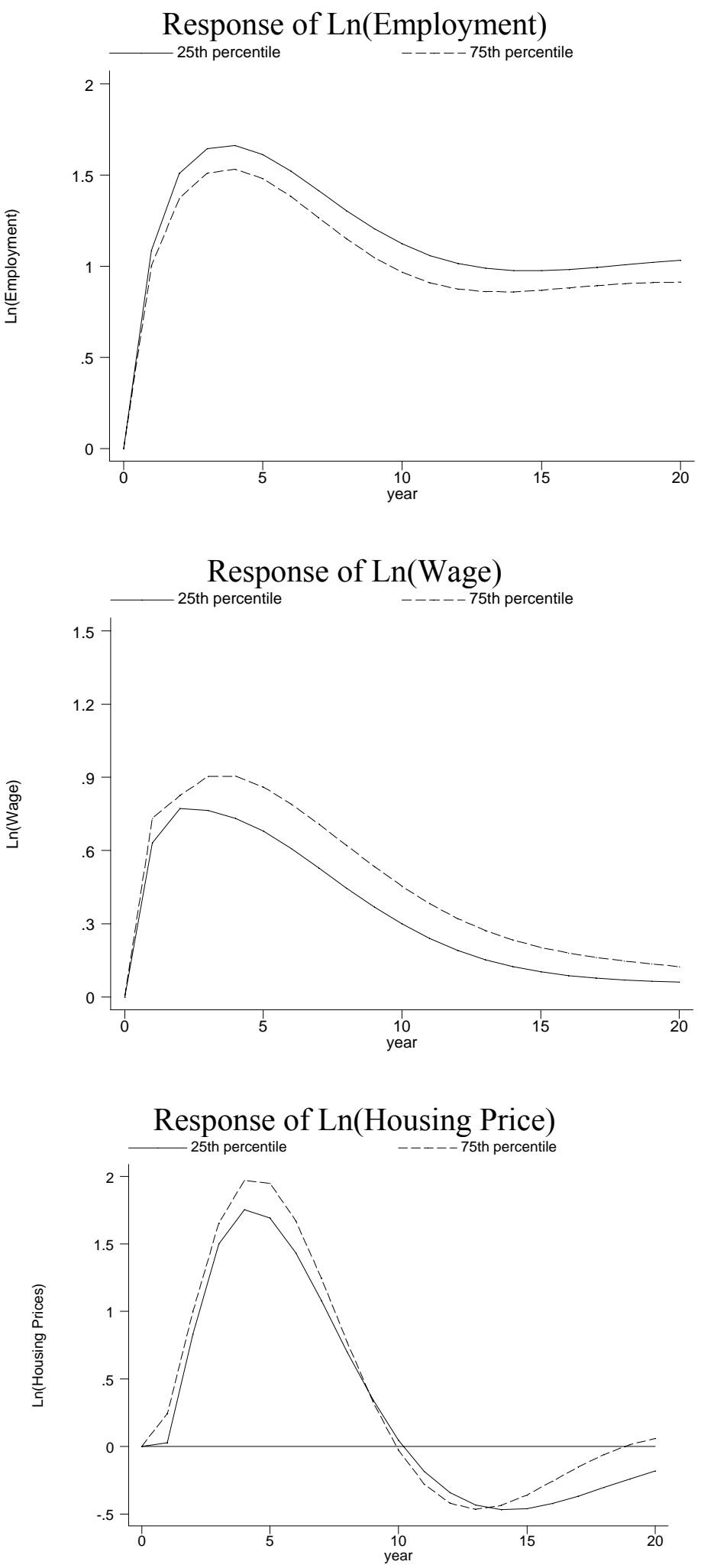
Figure 6

Distribution of Long-Run Employment Responses

to a 1 Percent Increase in Labor Demand

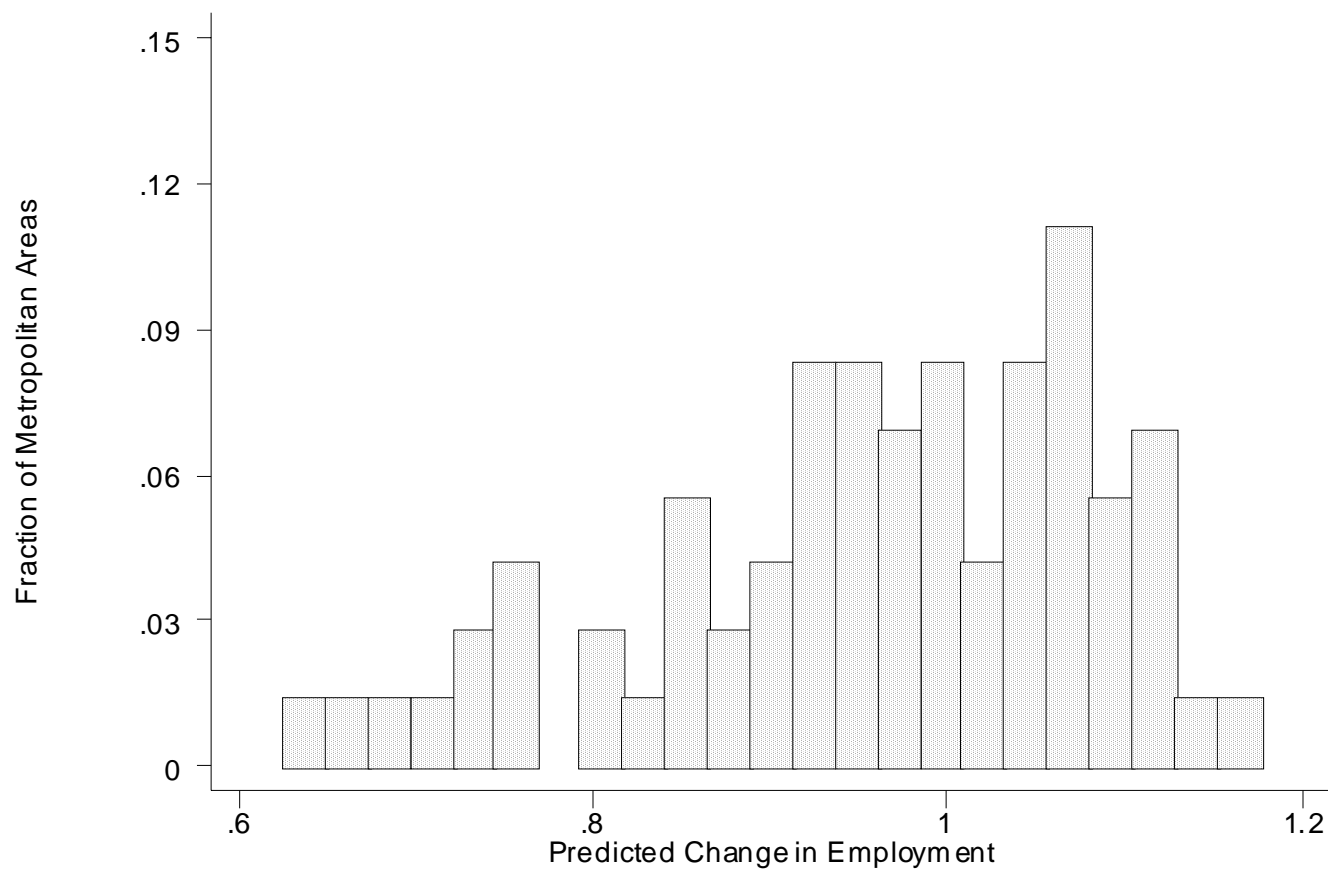




\section{Data Appendix}

\section{Constructing an Index of Housing Supply Regulation}

I create an index of housing supply regulation using information from six separate sources:

1. Wharton Urban Decentralization Project (Wharton, Linneman et al., 1990). In the late 1980s, researchers at the Wharton School of the University of Pennsylvania surveyed city planners and local county officials concerning local development regulations. The project collected information on building codes, zoning laws, and many other local government policies aimed at controlling the supply of residential real estate. I combine the answers to the following nine survey questions into a single measure of housing supply regulation: the average length of time for re-zoning permits to be approved, the average length of time for subdivision permits to be approved, the change in zoning approval time from 1983-88, the fraction of zoning applications approved, a rating of the adequacy of the provision of infrastructure for growth needs, a rating of the importance of regulation and development standards in the development process, the amount of impact fees per housing unit, the presence of growth management policies, and the importance of various methods growth management. The answers to each question are normalized to have a mean of zero and a variance of 1 , and then averaged across all nine answers.

2. Regional Council of Governments (RCG, Segal and Srinivasan, 1985). In a survey carried out between 1975-1978, Segal and Srinivasan asked members of the Regional Council of Governments to estimate the fraction of suburban land that had been made unavailable for development through government regulations. This measure ranges from 0 (many metropolitan areas such as Dallas, TX and Rochester, NY) to 43.5 percent (Sacramento, CA).

3. International City Management Association (ICMA). In 1984, the International City Management Association sent out a survey on economic development to municipal chief administrative officers. I use the responses to 4 questions related to constraints on construction:

$$
\text { Index }=\text { enimtx }+ \text { histpsx }- \text { ennrx }- \text { zongx }
$$

where enimtx $=1$ if the city requires developers to prepare an environmental impact statement

histpsx $=1$ if the city is involved in historic preservation

ennrx $=1$ if the city has altered environmental regulations to facilitate economic development

zongx $=1$ if the city has reformed building or zoning regulations to facilitate economic development

I aggregate the responses for each city to metropolitan areas using 1990 land area as weights. The data are available through the FAUI project (see below). ${ }^{24}$

4. Fiscal Austerity and Urban Innovation (FAUI, Clark, 1994). As part of a large survey of local city governments, chief administrative officers were asked to rate the importance of imposing controls on new construction as a method of limiting population growth. Answers ranged on a scale equal to 1 for least important and 5 for most important. The

\footnotetext{
${ }^{24}$ I thank Terry Clark for providing the data and original survey documentation.
} 
survey was conducted in 1983-84. The responses for each city are aggregated to metropolitan areas using 1990 land area as weights.

5. National Register of Historic Places (NRHP). The NRHP maintains a comprehensive database of all properties of historic significance in the United States that are listed in the National Register. The database includes historic buildings, sites, districts, structures, and objects and has information on the location, size, date of certification, and other characteristics of each property. I calculate the total amount of land area in each metropolitan area taken up by a historic district or site. ${ }^{25}$ Because the information on lot size is generally missing for other types of places, I separately add up the total number of buildings and structures that are not in a district or site. Then, I create a measure of historic preservation equal to the average of the number of buildings and structures per square mile and the fraction land in the metropolitan area that is a part of a historic district or site.

6. American Institute of Planners (AIP, American Institute of Planners, 1976). In 1976, the AIP conducted a study of they types of land use planning activity undertaken by each of the 50 states. I create an index based on the presence or absence of eight different policies with the potential to restrict residential construction: comprehensive land use planning, coastal zone management plans, wetlands management regulations, floodplain management, designation of some "critical" locations as requiring state involvement for development, legislation regulating the location and development of new towns, requirements for developers to file environmental impact statements, and regulations preempting local regulations for "developments of greater than local impact." A state is assigned a value of 1 for each type of policy it uses, and the final score for each state is the sum over all eight policies. For metropolitan areas that extend into multiple states, I use a weighted average of the state scores where the weights are determined by the fraction of land that extends into each state.

The comprehensive index of housing supply regulation is a simple average of each of the six surveys described above. Because the geographic areas covered by the first four surveys are different, I impute missing values for each survey from observed values of the other surveys. For each metropolitan area, I use the largest number of other surveys possible to impute any missing values. I start with an OLS regression of one survey on the remaining 5 and use the estimated coefficients to predict missing values. Then I exclude one of the surveys from the regression and repeat the prediction. Since the second regression is based on a fewer number of independent variables, it will require fewer variables to be non-missing. Therefore, it will be based on a larger number of observations and will make predictions for a broader set of metropolitan areas. I repeat this approach, dropping one dependent variable at a time and then pairs of dependent variables at a time, and so on until all missing values of an index are imputed. To illustrate the degree of correlation between each of the surveys, Appendix Table 1 shows the bivariate correlation between each pair of surveys and the number of metropolitan areas that they have in common. Because the NRHP index displays a low correlation with all of the other measures, I do not use it in any of the imputation equations. After all missing values are imputed, I rescale each index to have a mean of zero and a standard deviation of one. The final index of supply regulation is a simple average of these six components. Although the imputation

\footnotetext{
${ }^{25}$ The database contains information on the county where each property is located, so I use the 1999 Census definitions of metropolitan areas to be consistent with the rest of the analysis.
} 
strategy has the potential to predict missing values for all 318 metropolitan areas in the United States, I limit the analysis to areas with at least 2 non-imputed values among the Wharton, RCG, ICMA and FAUI surveys. The final index covers a total of 82 metropolitan areas and the complete ranking is shown in Appendix Table 2.

An alternative method of combining these six surveys would be to extract a common component using factor analysis. This strategy yields a component with an eigenvalue of 2.9 and positive factor loadings on all six surveys. The factor gives about equal weight to each of the four land-use surveys, and a bit less to the index of historic preservation and the state-wide regulations. $^{26}$ Computing an index of regulation this way yields similar results to using the simple average.

In the text, I discuss four specific types of housing supply regulation that are also derived from the six surveys described above. The measures of state regulation and historic preservation are simply equal to the AIP and NRHP surveys, respectively. The index of building permit restrictions is based on the answers to three specific questions in the Wharton survey: the average number of months it takes for subdivision or re-zoning permits to be approved, the fraction of permit applications approved, and the importance of building permits in growth management. The answers to these questions are scaled to have a mean of zero and standard deviation of 1, and the index of permit regulation is an average of the three. The index of growth controls is derived from both the Wharton and FAUI surveys. From the Wharton survey, I use a qualitative rating of the importance of each of the following factors as growth management techniques: population limits, zoning and other ordinances, and building permits. These responses are rated from 1 (not important) to 5 (very important). Because the question from the FAUI survey is also related to growth controls and the same rating was used in both surveys, the growth control index is equal to an average of the two measures in metropolitan areas where both are present, and equal to the value of a single measure in areas where only one of the two are available.

\section{Other Variables}

Wherever possible, all variables are calculated to reflect the 1999 Census definitions of Primary Metropolitan Statistical Areas and New England County Metropolitan Areas. Population, employment, the housing stock, and housing permits are all aggregated from county-level data according to these definitions.

Housing stock: Annual values of the housing stock are predicted from data on building permits for residential construction and the following stock-flow equation:

Stock $_{\text {it }}=$ Stock $_{\text {it-1 }}+$ Permits $_{i t}-$ Adjustment factor $_{\text {it }}$

This formula assumes that all residential building permits result in a completed housing unit within a year after they are issued. The methodology used by the Census Bureau is similar, although they assume that the time from permit to completion is only 6 months. Permits as defined as the sum of all residential permits in an area, including both single-family and multifamily units. I begin with the size of the housing stock from the 1980 Census and calculate decadal adjustment factors so that the 1990 and 2000 values predicted by the stock-flow equation match the Census counts. This adjustment will reflect metropolitan area and decade-specific housing loss, as well as any factors that prevent a building permit from leading to a completed

${ }^{26}$ The weights given to each survey are: Wharton, .29; RCG, .29; ICMA, .33; FAUI, .25; NRHP, .13; AIP, .04. 
housing unit. Estimates of the housing stock in 2001 and 2002 are taken directly from countylevel estimates provided by the Census Bureau's Population Estimates.

Housing prices: The average housing price for each metropolitan area is based on a repeat sales price index published by the Office of Federal Housing Enterprise Oversight. This index uses data on the sales prices of individual homes and calculates price changes from homes that are sold multiple times. Because the index is based on repeated observations of the same home, changes in the quality of the housing stock over time will only impact the index when houses are renovated or depreciate significantly. The index is published on a quarterly basis, so I create an annual index that is equal to the average of the four quarters in each year. I re-base each index to be equal to the median housing value reported in the 1990 Census. Then, these values are translated into real terms by dividing by the PCE chain-price index. The indexes are published based on the 1999 Census definition of PMSAs. For PMSAs in New England, I assign the housing price index from the closest possible PMSA to each NECMA.

Employment: Employment is defined as total nonfarm employment in each metropolitan area, and is aggregated from county-level data from the Census Bureau's County Business Patterns.

Wages: Wages are calculated as total wage and salary disbursements divided by the number full-time equivalent employees as reported by the Bureau of Economic Analysis. Real values are calculated using the PCE chain-price index.

Unionization: I calculate the average share of unionized workers in each metropolitan area using the Merged Outgoing Rotation Groups of the Current Population Survey. The unionization rate is defined as the number of union members as a fraction of total employment. I exclude the construction industry in order to avoid any issues concerning the effect of union wages on construction costs. In order to improve the precision of the estimates, I calculate the unionization rate by pooling all years from 1986 to 2002.

State Regulatory Index: This index is taken from a state-level study on economic freedom conducted by Byers, McCormick and Yandle (1999) at Clemson University. They create an index of the general regulatory environment in a state using 23 separate measures of labor and school choice regulation, workers compensation, environmental legislation, and regulations in the trucking, insurance, and public utility industries. Most measures pertain to the late 1990s, and no direct measure of housing market regulation is included. Higher values of the index correspond to a stronger degree of regulation.

Metropolitan Area Age: I classify locations by the decade in which they became a metropolitan area, defined as having a central-city population greater than 50,000 and a total area population greater than 100,000. This information is reported in Bogue (1953). Bogue's classification divides areas into those established before 1900 and those established in each decade between 1900 and 1950. I group the remaining areas that were established after 1950 together in a seventh category. Metropolitan areas in the oldest category are assigned the highest value so that this variable is increasing in age. The following table shows the distribution of the sample across categories: 


\begin{tabular}{lc}
\hline Time period & $\begin{array}{c}\text { Fraction of } \\
\text { Metropolitan Areas }\end{array}$ \\
\hline Before 1900 & $31 \%$ \\
$1900-1910$ & $10 \%$ \\
$1910-1920$ & $12 \%$ \\
$1920-1930$ & $10 \%$ \\
$1930-1940$ & $9 \%$ \\
$1940-1950$ & $11 \%$ \\
$1950-$ present & $17 \%$ \\
\hline
\end{tabular}

Labor demand shocks: Following Bartik (1991), I predict changes in employment growth based on the industrial composition of each metropolitan area and national industrial growth. In each location, the predicted growth in labor demand is a weighted average of national industry growth rates, where the weights are equal to the share of an industry's employment relative to total metropolitan area employment. To be specific, the formula I use is:

$$
\begin{aligned}
& \hat{\varepsilon}_{i t}^{d}=\sum_{j=1}^{59} \frac{e_{i j t-1}}{e_{i t-1}}\left(\frac{\widetilde{e}_{i j t}-\widetilde{e}_{i j t-1}}{\widetilde{e}_{i j t-1}}-\frac{e_{t}-e_{t-1}}{e_{t-1}}\right) \\
& \text { where } i=\text { MSA, } j=\text { industry, } t=\text { year } \\
& \widetilde{e}_{i j t}=\text { national industry employment outside of MSA } i=e_{j t}-e_{i j t} \\
& e_{i t}=\text { metropolit an area employment }=\sum_{j=1}^{59} e_{i j t} \\
& e_{t}=\text { national employment }=\sum_{i=1}^{318} e_{i t}
\end{aligned}
$$

The formula above shows that the industry employment growth rates are adjusted to (1) exclude local employment growth when calculating industry employment growth rates and (2) express industry employment growth relative to national employment growth. Employment in each metropolitan area is defined at the 2-digit SIC level using data from the County Business Patterns and aggregated to the metropolitan level using 1999 PMSA and NECMA definitions. For the years 1998-2002, I define industries using 3-digit NAICS. Because the definition of an establishment changes over time in the County Business Patterns data, I use data from the Bureau of Labor Statistics to calculate national industry employment growth rates. I omit the construction industry because changes in construction industry employment are likely to be related to housing supply regulation, and I omit agricultural employment because the BLS does not report employment in these industries.

Low-demand metropolitan areas: In order to identify metropolitan areas with a relatively low degree of housing demand during the past two decades, I use information on population growth and housing price appreciation from 1960 to 1980. To be specific, an area is defined as having low housing demand if it experienced an average annual rate of population growth of less than 1.1 percent and relative housing price growth of less than 0.4 percent from 1960-1980. These values correspond to about the lowest $35^{\text {th }}$ percentile of the population growth and price growth distributions. Housing prices are measured using the median value of single-family homes from 
the 1960 and 1980 Census. I calculate the average housing price for each metropolitan area by weighting each county by the number of single-family homes and using 1999 MSA definitions of metropolitan areas to determine which counties to include in each metropolitan area. Housing prices are expressed relative to construction costs using city-specific construction cost indexes published by the R.S. Means Company. This methodology identifies the following 27 locations as having low housing demand:

$\begin{array}{lll}\text { Akron, OH } & \text { Detroit, MI } & \text { Rockford, IL } \\ \text { Albany-Schenectady-Troy, NY } & \text { Flint, MI } & \text { Shreveport-Bossier City, LA } \\ \text { Beaumont-Port Arthur, TX } & \text { Gary, IN } & \text { South Bend, IN } \\ \text { Binghamton, NY } & \text { Indianapolis, IN } & \text { Springfield, MA } \\ \text { Buffalo-Niagara Falls, NY } & \text { Jersey City, NJ } & \text { St. Louis, MO-IL } \\ \text { Chicago, IL } & \text { Louisville, KY-IN } & \text { Syracuse, NY } \\ \text { Cincinnati, OH-KY-IN } & \text { Mobile, AL } & \text { Toledo, OH } \\ \text { Cleveland-Lorain-Elyria, OH } & \text { Omaha, NE-IA } & \text { Utica-Rome, NY } \\ \text { Dayton-Springfield, OH } & \text { Rochester, NY } & \text { Youngstown-Warren, OH }\end{array}$


Appendix Table 1

Correlation of Housing Supply Survey Measures

\begin{tabular}{|c|c|c|c|c|c|c|}
\hline & Wharton & RCG & ICMA & FAUI & NRHP & AIP \\
\hline \multirow[t]{2}{*}{ Wharton } & 1 & .50 & .45 & .60 & .08 & .28 \\
\hline & (60) & (40) & (43) & (27) & (60) & $(60)$ \\
\hline \multirow[t]{2}{*}{$\mathrm{RCG}$} & & 1 & .66 & .45 & -.09 & .36 \\
\hline & & (48) & (33) & $(25)$ & (48) & (48) \\
\hline \multirow[t]{2}{*}{ ICMA } & & & 1 & .13 & .04 & .06 \\
\hline & & & (155) & (46) & $(155)$ & (155) \\
\hline \multirow[t]{2}{*}{ FAUI } & & & & 1 & -.13 & .02 \\
\hline & & & & (62) & (62) & $(62)$ \\
\hline \multirow[t]{2}{*}{ NRHP } & & & & & 1 & -.02 \\
\hline & & & & & (318) & (318) \\
\hline AIP & & & & & & $\begin{array}{c}1 \\
(318)\end{array}$ \\
\hline
\end{tabular}

Note. Each cell shows the bivariate correlation between each pair of survey responses. The number of observations that each pair has in common is shown in parentheses. 


\section{Appendix Table 2 \\ Ranking of Metropolitan Areas by Degree of Housing Supply Regulation}

(High Values Indicate More Regulation)

\begin{tabular}{cl}
\hline Index Value & Metropolitan Area Name \\
\hline-2.40 & Bloomington-Normal, IL \\
-1.96 & Buffalo-Niagara Falls, NY \\
-1.65 & Nashville, TN \\
-1.50 & Owensboro, KY \\
-1.48 & Joplin, MO \\
-1.37 & Pueblo, CO \\
-1.36 & Champaign-Urbana, IL \\
-1.32 & Oklahoma City, OK \\
-1.26 & Dayton-Springfield, OH \\
-1.23 & Richmond-Petersburg, VA \\
-1.18 & Dallas, TX \\
-1.15 & Killeen-Temple, TX \\
-1.07 & Lubbock, TX \\
-1.07 & Beaumont-Port Arthur, TX \\
-1.01 & Chicago, IL \\
-0.95 & Kansas City, MO-KS \\
-0.91 & Phoenix-Mesa, AZ \\
-0.85 & Little Rock-North Little Rock, AR \\
-0.77 & Atlanta, GA \\
-0.69 & Detroit, MI \\
-0.68 & Rochester, NY \\
-0.68 & Denver, CO \\
-0.66 & St. Louis, MO-IL \\
-0.66 & San Antonio, TX \\
-0.65 & Grand Rapids-Muskegon-Holland, MI \\
-0.64 & Topeka, KS \\
-0.55 & Indianapolis, IN \\
-0.52 & Houston, TX \\
-0.47 & Greensboro-Winston-Salem-High Point, NC \\
-0.46 & Birmingham, AL \\
-0.45 & Allentown-Bethlehem-Easton, PA \\
-0.32 & Orange County, CA \\
-0.27 & Vallejo-Fairfield-Napa, CA \\
-0.25 & Cleveland-Lorain-Elyria, OH \\
-0.22 & Louisville, KY-IN \\
-0.20 & New Orleans, LA \\
-0.16 & Minneapolis-St. Paul, MN-WI \\
-0.14 & Raleigh-Durham-Chapel Hill, NC \\
-0.12 & Hartford, CT \\
-0.09 & Wichita Falls, TX \\
-0.07 & Columbus, OH \\
\hline & Laredo, TX \\
\hline
\end{tabular}




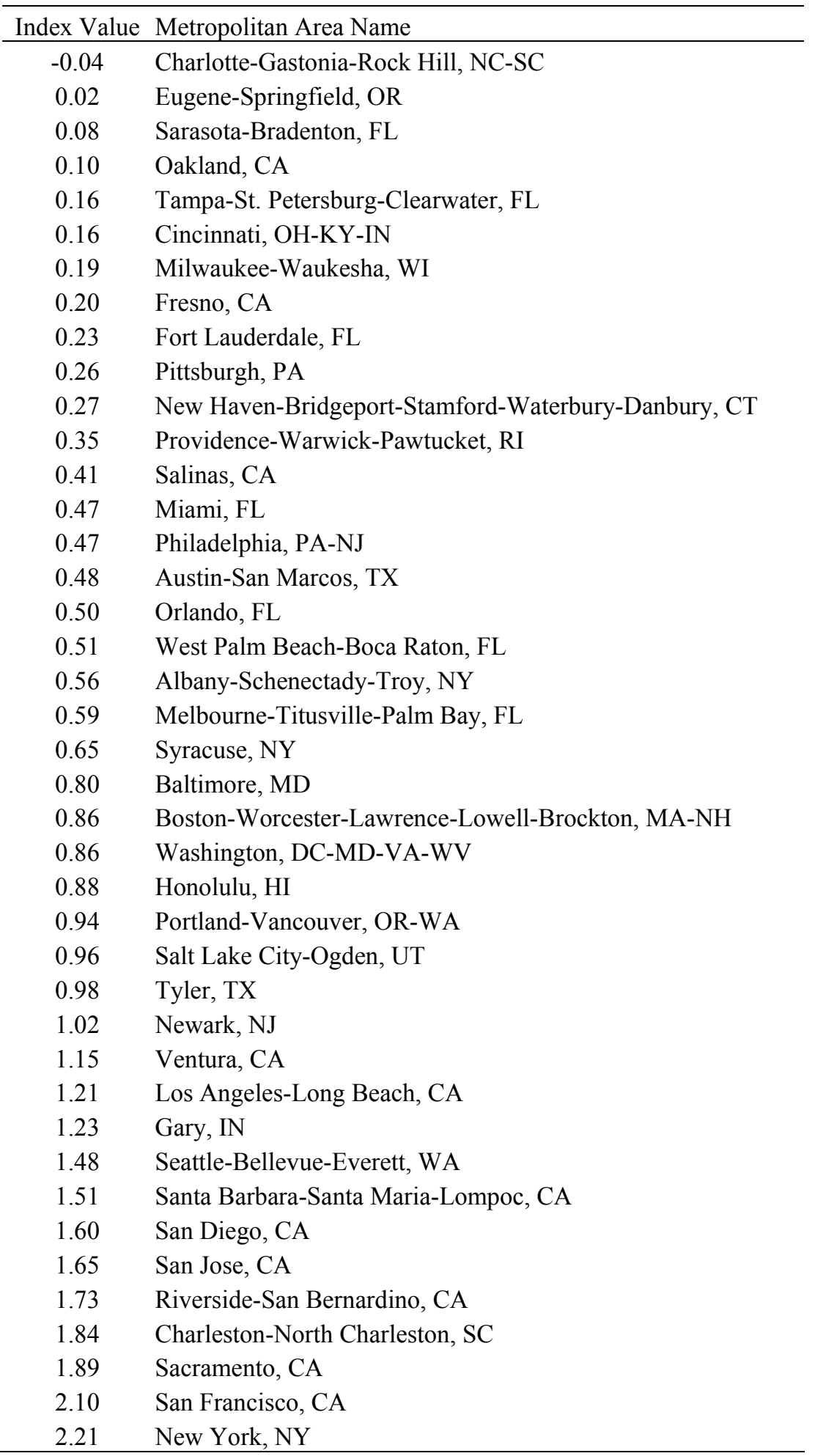

